Exchange Rate Pass-Through, Domestic Competition, and Inflation: Evidence from the 2005/08 Revaluation of the Renminbi

Raphael A. Auer

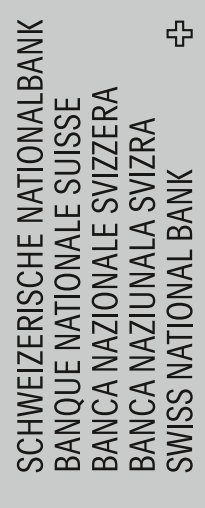


The views expressed in this paper are those of the author(s) and do not necessarily represent those of the Swiss National Bank. Working Papers describe research in progress. Their aim is to elicit comments and to further debate.

\section{Copyright $\odot$}

The Swiss National Bank (SNB) respects all third-party rights, in particular rights relating to works protected by copyright (information or data, wordings and depictions, to the extent that these are of an individual character). SNB publications containing a reference to a copyright ( $\odot$ Swiss National Bank/SNB, Zurich/year, or similar) may, under copyright law, only be used (reproduced, used via the internet, etc.) for non-commercial purposes and provided that the source is mentioned. Their use for commercial purposes is only permitted with the prior express consent of the SNB.

General information and data published without reference to a copyright may be used without mentioning the source.

To the extent that the information and data clearly derive from outside sources, the users of such information and data are obliged to respect any existing copyrights and to obtain the right of use from the relevant outside source themselves.

\section{Limitation of liability}

The SNB accepts no responsibility for any information it provides. Under no circumstances will it accept any liability for losses or damage which may result from the use of such information. This limitation of liability applies, in particular, to the topicality, accuracy, validity and availability of the information.

ISSN 1660-7716 (printed version)

ISSN 1660-7724 (online version)

๑ 2012 by Swiss National Bank, Börsenstrasse 15, P.0. Box, CH-8022 Zurich 


\title{
Exchange Rate Pass-Through, Domestic Competition, and Inflation: Evidence from the 2005/08 Revaluation of the Renminbi.*
}

\author{
Raphael A. Auer ${ }^{\dagger}$ \\ January 6, 2012
}

\begin{abstract}
This paper quantifies the effect of the government-controlled appreciation of the Chinese renminbi (RMB) vis-à-vis the USD from 2005 to 2008 on the prices charged by US producers. As the RMB during that time was pegged to a basket of currencies, the empirical strategy must account for the fact that the currencies included in the basket may have directly affected US prices. Thus, the pre-2005 period is used to filter out the effects of other exchange rates on import and producer prices. Additionally, utilizing the remainder of the sample, the pure effect of an RMB appreciation on US import prices and, in turn, the effect of RMB-induced US import price fluctuations on US producer prices is established. In a panel spanning the period from 1994 to 2010 and including 417 manufacturing sectors, the main finding emerging from this empirical strategy is that import prices pass into producer prices at an average rate of 0.7. This finding supports the view that the markets for domestic and imported manufactured goods are well integrated. Consequently, even if the exchange rate affects import prices only to a small extent, it may have a substantial impact on inflation, as it exerts a sizeable impact on the competitive environment of domestic producers and the prices that they charge.
\end{abstract}

Keywords: Price Complementarities, Exchange Rate Pass Through, China, Inflation, Markups

JEL Classification Number: F11, F12, F14, F15, F16, F40, E31, L16

${ }^{*}$ I thank Jessica Leutert for excellent research assistance and Mary Amiti, Natalie Chen, Etienne Gagnon, Joseph E. Gagnon, Linda Goldberg, Luca Guerrieri, Christopher J. Gust, Rebecca Hellerstein, Jean Imbs, Maurice Obstfeld, John H. Rogers, Raphael Schönle, Robert J. Vigfusson, Jian Wang and seminar participants at the Board of Governors of the Federal Reserve System, the European Central Bank, the Federal Reserve Bank of New York, the International Monetary Fund, and at the 2011 Conference on Exchange Rates and External Adjustment of the Bank of Canada and the European Central Bank for comments. The views expressed in this document are solely those of the author and do not necessarily reflect those of the Swiss National Bank

${ }^{\dagger}$ Swiss National Bank; raphael.auer@snb.ch. 


\section{Introduction}

The topic of global imbalances in general and China's exchange rate policy against the US dollar in particular is currently the "most salient of controversies in international monetary economics" (Frankel (2010)). There are not many signs that the discussion will end any time soon. US policymakers have repeatedly demanded that China revalue its currency by $20 \%$ to $40 \%$ (see, for example, Geithner (2009)). These demands have consistently been rebuked by Chinese government officials.

Rather surprisingly, the inflationary danger that such an appreciation could cause has not been discussed in this policy debate. After all, the increase in cheap imports from China was a major contributing factor to the low-inflation environment during the last two decades. ${ }^{1}$ If economic policies, such as a marked appreciation of the Renminbi (RMB), successfully reduce global imbalances, the disinflationary effect of cheap Chinese imports will, at least partly, be reversed.

In 2010, Chinese exports to the US were worth over 300 billion USD. This figure implies that nearly a sixth of the manufactured goods consumed in the US are actually made in China (see Rynn (2005)). What would happen to US inflation if the firms producing one in six of the goods in the average US consumer's shopping basket, including virtually all of the clothing, toys, consumer electronics, and probably the shopping basket itself, suddenly faced $20 \%$ to $40 \%$ higher labor costs? Such an event would have a substantial direct impact on inflation because of the weight of Chinese goods in the US consumer price index (CPI). More importantly, such a dramatic shock might alter the equilibrium of the prices in many industries and lead to widespread inflationary dynamics also in the U.S. domestic economy.

This paper quantifies the indirect inflationary effect of an RMB appreciation on the competitive environment in US producer markets and the prices that domestic producers charge. The main finding of this paper is that the pass-through rates of import prices into producer prices is high. In a panel of import and producer prices including 417 manufacturing sectors and spanning the period from 1994 to 2010, the rate at which import prices pass through into producer prices is estimated between 0.55 to 1 . This finding of high passthrough rates supports the view that the markets for domestic and imported manufactured goods are well-integrated. Consequently, even if the exchange rate affects import prices only to a small extent, it may still have a substantial impact on aggregate inflation, as the exchange rate has a sizeable impact on the overall domestic price level.

The empirical analysis examines how the RMB appreciation is passed through into US import prices and, in turn, how these import prices affect US producer prices. The first part of this exercise is motivated by recent advances studying the microeconomic determinants of

\footnotetext{
${ }^{1}$ See International Monetary Fund (2008), Bugamelli et al. (2009), Auer and Fischer (2010), and Auer et al. (2010). Bernard et al. (2006) previously established the large effect of low-wage import competition on U.S. manufacturing dynamics.
} 
exchange rate pass through into import prices $^{2}$ and the literature quantifying how exchange rate movements pass through into aggregate price indices. ${ }^{3}$

The first difference between this study and the recent literature on exchange rate passthrough is the focus on domestic prices. In the analysis below, the principal dependent variable of interest is US producer prices, which is measured as the "prices received by domestic producers for their output" (see Bureau of Labor Statistics (2010)), emphasis added). ${ }^{4}$ China is the world's largest exporter, and the appreciation of the RMB will affect the equilibrium prices that US producers charge. In this paper, I aim to quantify the indirect effect of exchange rate changes on domestic price setting. In this sense, the empirical exercise most closely related to this study is Chen et al. (2009), who analyze how long-run changes in import competition affect the intensity of competition and the prices of domestic firms. I do not analyze the long-run effect of increasing trade integration but the short-run dimension of how fluctuations in the exchange rate affect the domestic competitive environment via price complementarities. The notion that price complementarities matter also underlies the analysis of Gust et al. (2010 and 2011), who analyze how increasing trade integration can lead to a lower degree of exchange rata pass through, and of Atkeson and Burstein (2008), who examine whether a framework of imperfect competition and variable markups can reproduce main features of differences and fluctuations in international relative prices. ${ }^{5}$

The second difference between this study and the existing literature is that this study focuses on the exchange rate pass-through following a government-controlled appreciation instead of market-determined exchange rate fluctuations. It is important to acknowledge

\footnotetext{
${ }^{2}$ One branch of research focuses on structural estimation of pricing-to-market and exchange rate passthrough, mostly in the car industry (Knetter (1989 and 1993) and P. Goldberg and Verboven (2001 and 2005); see also the work of Hellerstein (2008) and Nakamura and Zerom (2010) for the cases of the beer and coffee industries, respectively). More recent studies focus on reduced-form pass-through regressions in micro-datasets spanning many industries (see Gopinath and Rigobon (2006), Gopinath and Itskhoki (2010a and b), Gopinath et al. (2010), and Neiman (2010)).

${ }^{3}$ See, among others, Yang (1997), Giovannini (1988), Froot and Klemperer (1989), Devereux and Engel (2002), Corsetti et al. (2004), Jeannine and Fujiisee (2004), Campa and L. Goldberg (2005), Atkeson and Burstein (2009), Auer and Chaney (2007 and 2009), and OL. Goldberg and Campa (2010). Additionally, see P. Goldberg and M. Knetter (1997) for a survey of an earlier analysis in the area of exchange rate pass-through.

${ }^{4}$ Bacchetta and Van Wincoop (2003), Burstein et al. (2003), and L. Goldberg and Campa (2010) argue that distribution cost intensity plays a major role in the rate of pass-through into consumer prices. Because the BLS considers retailing and wholesaling as services that are provided separately from the good itself (see Bureau of Labor Statistics (2010)), producer prices account for a much smaller share of the distribution costs than consumer prices.

${ }^{5}$ Chen at al. (2009) also build a theoretical foundation explaining why and how imports affect the general toughness of competition and the prices of domestic firms. These authors use preferences featuring price complementarities of Ottaviano et al. (2002) and Melitz and Ottaviano (2005). Gust et al. (2010) analyze the pricing response of firms to exchange rate shocks using the framework of Kimbal (1995) and Dotsey and King (2005), where preferences are such that a firm's demand elasticity is increasing in its relative price compared to its competitors (also see Bergin and Feenstra (2001)). Atkeson and Burstein (2008) build on a model featuring strategic prices complementarities that draws on Dornbush (1987).
} 
that the Chinese appreciation policy from 2005 to 2008 was not exogenous to other macroeconomic shocks that could have moved the US prices. In particular, as argued by Frankel and Wei (2008), during this period, the RMB was essentially pegged to a currency basket with equal weights on the USD and the euro. Therefore, the analysis presented herein does not only include the periods during which the RMB appreciated. Rather, I also focus on the effects of the policy changes at the start or the end of the RMB appreciations. In particular, the analysis utilizes the periods during which the RMB was pegged to the USD to filter out the effects of the other exchange rates on the import and producer prices. Second, utilizing the remainder of the sample, I establish the pure effect of an RMB appreciation on US import prices and, in turn, the effect of RMB-induced US import price fluctuations on US producer prices.

The analysis presented in this paper proceeds in five steps. In the first step, I discuss the Chinese exchange rate policy and show how the Chinese government's policy switches can be used to establish the effect of imports on producer prices.

The second step of the paper analyzes how the RMB exchange rate affected the prices of goods imported from China and the aggregate US import price indices (IPI). This step primarily documents that the RMB exchange rate alone had a substantial impact on the IPI from 2005 to 2008. The pass-through rate of the RMB into the IPI is estimated to be, on average, approximately 0.20 . The combined pass-through rate of all of the other currencies is also estimated to be approximately $0.20{ }^{6}$ Thus, the analysis finds that a $1 \%$ movement of the RMB has nearly the same effect on US import prices as a $1 \%$ movement of all other currencies together. This result is surprising given that in the sample of this study, China accounts for approximately $22 \%$ of all imports $(30 \%$ towards the end of the sample).

The third part of the analysis examines how the RMB-induced fluctuations of US import prices influence the prices that US firms charge using a two-stage least squares (2SLS) estimation. The analysis focuses on establishing the effect of the switch from a fixed exchange rate regime lasting from 1994 to 2005 to a regime of gradual appreciation from 2005 to 2008 (followed by another switch to a fixed regime until mid-2010). In a sample covering the period from 1994 to mid-2005 as a control period and then the time leading up to 2010 to evaluate how the pace of the RMB appreciation affects prices, I find that the import prices affect the producer prices of traded goods at an average rate of approximately 0.7. This result implies that a $10 \% \mathrm{RMB}$ appreciation increases US producer prices by approximately $1.4 \%(=10 \% * 0.20 * 0.7)$. This result holds over a range of robustness tests and various time horizons.

To explain the mechanisms underlying the strong responses of domestic firms to foreign prices, the fourth step of the analysis investigates whether the pass-through rate is heterogeneous across sectors. I repeat the first-stage estimations, the reduced-form estimations

\footnotetext{
${ }^{6}$ This finding is roughly in line with the results of the recent literature documenting that the rate of pass-through into the US IPI is currently rather low and takes values ranging from approximately $10 \%$ to 15\% (compare to Marazzi et al. (2005), Marazzi and Sheets (2007), and Gust et al. (2010)).
} 
and the 2SLS specifications dividing the sample by sector characteristics, such as the labor intensity of production, traded input intensity, the shape of the demand for the sectors' goods, and general trade openness. This analysis suggests that price complementarities are the underlying mechanism explaining the price response. Additionally, the analysis also shows that the price response is partly explained by the effect of imported intermediate imports that affect the production costs of U.S. firms.

The fifth and last step of the analysis uses these findings to quantify the overall inflationary impulse of an RMB appreciation on the general inflation rate of US producer prices. I thus simluate the effect of a appreciation of the RMB, accounting for the fact that the pricing response is heterogeneous across sectors and across time, as well as for the autoregressive structure of producer and import prices. Once the price response at the sectoral level is estimated, I multiply each impact by the sector's weight in the overall PPI. Finally, I add together all of the weighted impulses at the sector level to obtain the magnitude of the total shock as a percentage of the overall US PPI.

In particular, I investigate the size of the overall shock as a percentage of the PPI if the RMB appreciates by $25 \%$ within 10 months or 25 months. These simulations reveal that a rapid RMB appreciation would lead to relative price shocks that are economically too large to ignore. For the scenario in which the RMB appreciates over 10 months at a rate of $2.5 \%$ per month, the total relative price shock expressed as a percentage of the US PPI inflation rate is predicted to be over 4 percentage points. Moreover, the relative price shocks caused by the appreciation is also likely to affect the equilibrium inflation rate in the US, as the price shocks are shown to have a strong influence on the sectoral distribution of price changes. A rapid appreciation would cause a strongly right-skewed distribution of shocks to US producer prices. In the presence of menu costs, the skewness of relative shocks affects the equilibrium inflation because of the asymmetric price responses of firms to small and large shocks (see Ball and Mankiw (1995)).

It is found that a slower rate of appreciation may be instrumental in containing the effects on US inflation. In the second scenario, where the RMB appreciates at $1 \%$ per month for 25 months, the total relative shock expressed in terms of the PPI inflation rate does not exceed 2 percentage points, but the effect is obviously more long-lived, as the total relative shock on the US producer price index hovers at approximately 1 percentage point for a period of nearly two years. However, because such an appreciation would not greatly affect the distribution of price shocks, the overall effect on US inflation may be well-contained. ${ }^{7}$

Overall, these findings support the view that, as the markets for domestic and imported manufactured goods are well integrated, the exchange rate may still have a substantial

\footnotetext{
${ }^{7}$ As a supplemental exercise, I also investigate the response of the import volume from China to the RMB exchange rate. I find that the volume of imports is quite elastic to exchange rate changes, with a long-run (i.e., 24 to 36 months after an appreciation) elasticity of import volume to exchange rate changes equal to approximately -5 . However, the response occurs slowly, with the import volume being nearly unaffected even 16 months after the exchange rate shock.
} 
impact on inflation even if the exchange rate affects import prices only to a small extent, as it has a sizeable impact on the competitive environment of domestic producers and the prices that they charge. Policies that fix the US-Chinese trade balance will inevitably create large relative price shocks in the US and may well inflate the economy at large. Both US and Chinese policymakers must consider these possibilities when deciding on a course of action.

The outline of this paper is as follows. Section 2 discusses the Chinese exchange rate policy and the regime changes observed during the last two decades. Additionally, this section discusses how these regime changes can be utilized to identify the effect of the appreciation of the RMB from 2005 to 2008. Section 3 presents the data. Section 4 presents the results regarding the effect of the RMB appreciation on import prices and Section 5 the effects on producer prices. Section 6 analyzes the heterogeneity of the response across sectors. Section analyses the response of import volume to the appreciation 5. Section 7 constructs simulations of the overall impact of a RMB appreciation at the currency juncture, and Section 8 concludes the study.

\section{Identifying the Effects of the Chinese Exchange Rate Policy}

Perhaps as a reaction to prior criticisms (see Bosworth (2004) and Overholt (2003)) of a decade-old policy to keep the RMB fixed at a rate of $8.28 \mathrm{RMB} / \mathrm{USD}$, the Chinese authorities announced in June 2005 that they would switch to a new exchange regime in which the RMB is fixed to a basket of currencies.

Because neither the precise basket of currencies nor the underlying weights were ever published, there has been a considerable debate on which currency policy China actually followed during this episode (see Frankel and Wei (2007 and 2008) and Frankel (2009)). Although it is not precisely known why the Chinese government decided to revalue the RMB from time to time, the unambiguous result is that from 2005 to 2008, the RMB appreciated a combined $17.5 \%$ against the dollar (19\% in terms of the natural logarithm). Figure 1 documents the evolution of the RMB/USD exchange rate since 1999 and the pronounced appreciation of the RMB that occurred during this period.

Given that China is currently the largest trade partner of the US, this permanent appreciation should also have had a sizeable effect on the US macroeconomy. However, Figure 1 documents the evolution of the EUR/USD exchange rate and suggests the following problem with this analysis. The RMB did not vary independently; rather, the rate of appreciation depended on the evolution of the euro. Frankel and Wei (2007 and 2008) carefully estimate the extent of this co-movement and find that the Chinese probably followed a currency basket that gave at least as much weight to the euro as it did to the USD. This finding is problematic, as the EUR/USD exchange rate on its own has a sizeable effect on US prices. 
How, then, can one establish the effect of the Chinese exchange rate policy if the path of the RMB during the appreciation period was itself only a function of other variables that might have directly affected US prices? It is straightforward to show that the principal endeavor of this paper can be easily recovered. To this end, let $\Delta p p i_{u s, t}$ denote the percentage change of US domestic prices and $\Delta i p i_{u s, t}$. Abstracting from other covariates, the principle equation of interest is the relation between domestic and import prices, that is

$$
\Delta P P I_{u s, t}=\alpha_{p p i}+\beta \Delta I P I_{u s, t}+\sum_{T P \neq C h i} \gamma_{i p i, T P} \Delta e_{U S D / T P, t}+\epsilon_{p p i, t}
$$

${ }^{8}$ Import prices, in turn are determined by the RMB exchange rate

$$
\Delta I P I_{u s, t}=\alpha_{i p i}+\delta_{R M B} \Delta e_{U S D / R M B, t}+\sum_{T P \neq C h i} \gamma_{i p i, T P} \Delta e_{U S D / T P, t}+\epsilon_{i p i, t} .
$$

Of course, when evaluating the effect of the RMB on import prices, one must also consider the fact that the government-controlled path of the RMB reacts to other exchange rates. In particular, the Chinese exchange rate policy is such that before $T_{\text {Shift }}$, the exchange rate is flat against the dollar, while after that date, it commoved with other exchange rates due to the fact that the Chinese implicitly were following a currency basket. Then, the movement of the USD-RMB exchange rate is given by

$$
\Delta e_{U S D / R M B, t}=\left\{\begin{array}{c}
0 \text { if } t \leq T_{\text {Shift }} \\
\alpha_{y u a}+\sum_{T P \neq C h i} \rho_{T P} \Delta e_{U S D / T P, t}+\epsilon_{\text {policy }, t}
\end{array} \text { if } t>T_{\text {Shift }}\right.
$$

where $\rho$ is equal to the weight of the ROW exchange rate in the Chinese currency basket. The government-controlled appreciation process (3) after $T_{\text {Shift }}$ poses a problem for the identification of the effects of the RMB appreciation, as the other exchange rates affect both import prices (2) and producer prices (1) directly on the one side, but on the other side the other exchange rates may also affect the path of the appreciation itself.

If one were to restrict the sample to $t>T_{\text {Shift }}$, one could identify the coefficients only from $\epsilon_{\text {policy,t }}$, the deviations of the Chinese exchange rate policy from its currency basket. For example, if one assumes that the euro/ USD exchange rate $\left(\Delta e_{U S D / E u r, t}\right)$ is the only covariates, the import price regression (2) would simplify to

$$
\Delta I P I_{u s, t}=\alpha_{i p i}+\left(\delta_{R M B} \rho_{e u r}^{\prime}+\gamma_{i p i}^{\prime}\right) \Delta e_{U S D / E u r, t}+\delta_{R M B} \epsilon_{\text {policy }, t}+\epsilon_{i p i, t},
$$

where the estimation can only distinguish the direct effect of the euro on US import prices from the indirect effect via influencing the RMB exchange rate if the variance of $\epsilon_{\text {policy,t }}$ is of a large enough magnitude compared to the variance of $\Delta e_{U S D / E u r, t}$. As document below, this is not the case, thus requiring a different approach.

\footnotetext{
${ }^{8}$ Equation (1) explicitly acknowledges that all exchange rates might be correlated with US macroeconomic shocks that also affect the US PPI.
} 
Inclusion of the pre-appreciation period in the sample enables to filter out the direct effects of the other exchange rates. Consider an estimation that first filters out the effect of the RMB appreciation. The sample is split up in two periods (i.e., before and after the shift in the policy regime). Estimating the import price regression (2) using the sample $t \leq T_{\text {Shift }}$ when the RMB is fixed yields the coefficient estimates $\gamma_{i p i, t \leq T_{\text {Shift }}}$. Then, one can generate the effect of the other exchange rates after $T_{\text {Shift }}$ by using the realizations of these exchange rates after $T_{\text {Shift }}$ and the estimated coefficients $\gamma_{i p i, t \leq T_{\text {Shift }}}$. That is, defining

$$
\Delta I{\widehat{P I u s, t>T_{S h i f t}}} \equiv \alpha_{i p i, u s, t \leq T_{S h i f t}}+\sum_{T P \neq C h i} \gamma_{i p i, t \leq T_{S h i f t}} \Delta e_{U S D / T P, t>T_{S h i f t}},
$$

an estimation of the Chinese exchange rate policy on the actual changes of import prices net of what is to be expected based on the evolution of other exchange rates yields the pure effect of the RMB exchange rate $\delta_{R M B}$ :

$$
\Delta I P I_{u s, t}-\Delta I P \widehat{I}_{u s, t \leq T_{\text {Shift }}}=\delta_{R M B} \Delta e_{U S D / R M B, t}+\epsilon_{i p i, t} .
$$

Similarly, the relation between producer prices and import prices (1) can be filtered in this manner.

Overall, the above points to a straightforward strategy for identifying the effect of the Chinese exchange rate policy vis-a-vis the USD. That is, I precisely identify the coefficient on the covariates based on the time period when the RMB was fixed to the USD and estimate the effect of the RMB fluctuations conditional on the effects of the other exchange rates being netted out from the import prices. In this sense, the identification in this paper is derived from the period during which the RMB was fixed to the USD and not from the appreciation period itself. ${ }^{9}$

\section{Data Description}

The analysis of this paper estimates the response of US import and producer prices in a monthly panel dataset spanning the years from January 1994 to December 2010 and including up to 418 different sectors. Trade data by sector and quarter are obtained from

\footnotetext{
${ }^{9}$ A related strategy would be to include all variables and estimate (3) and (2) in the entire sample spanning the time period from 1994 to 2010. Given that the pre-2005 variation identifies the effects of all of the covariates, the post-2005 variation can be attributed to either the effect of the covariates or to the RMB appreciation. If the true underlying coefficients were constant in the two parts of the sample, this approach would be identical to the previously discussed filtering strategy. However, in practice, this second approach needs to be modified by the inclusion of one additional dummy because during the pre-2005 period, the average rate of global inflation was much lower than it was from 2005 to 2008, which was a period characterized by rising prices around the globe. Thus, the estimation in the entire sample length includes one sub-period of 0 RMB appreciation and low inflation and another sub-period of high inflation and positive RMB appreciation. Consequently, the coefficient of the RMB appreciation is driven mostly by the differences between these two periods, rather than the variance in the path of the RMB within the appreciation period. I thank Rob Vigusen for pointing out this estimation problem.
} 
the United States International Trade Commission (USITC). The import data are classified based on the 6-digit North American Industry Classification System (NAICS). The General Customs Value is selected as the trade type.

Information on import prices is available from the Bureau of Labor Statistics (BLS) at various levels of aggregation. There are 55 import price indices at the 5 -digit level, 64 at the 4-Digit level, and 21 at the 3-digit level. To guarantee that all of the prices used in the analysis below are independent observations, I use the 55 price indices at the 5 -digit level and add to this the 4- or 3-digit prices for which either no 5-digit price is published or for which I can compute more 5-digit prices based on the difference between the import price indices at the 5-digit and 4-digit levels considering the respective import weights of index and subindices.

For example, if sector 1234 has two 5-digit subsectors $1234 A$ and $1234 B$, and if a 5 -digit price index is published for the 4-digit sector and for one 5-digit subsectors (e.g., $1234 A$ ), it is possible to construct the price index for subsector $1234 B$ using the formula

$$
\Delta I P I_{1234} w_{1234}=\Delta I P I_{1234 A} w_{1234 A}+\Delta I P I_{1234 B} w_{1234 B}
$$

where $w_{1234}, w_{1234 A}$, and $w_{1234 B}$ are the import shares of the respective $5-$ or 4 -digit sectors. I also use the same assignment process to allocate the information available at the 3 -digit level to the missing 4 -digit prices.

Information on producer prices is available from the BLS at the 6- and 5-digit level for all of the sectors for which import prices are available.

Information on sector characteristics, such as labor intensity or the sector's general openness to trade, is included in the data. This information is obtained from the Annual Survey of Manufacturers. This data restrict the analysis to manufactured goods (NAICS codes 311111 to 339999), as only these sectors are covered in the Annual Survey of Manufacturers.

The overlap of trade information from the USITC, information from the Annual Survey of Manufacturers, and price information from the BLS yields 118 sectors (at the 5-digit level) when working with import prices, and 418 sectors when working with producer prices.

A trade-weighted exchange rate index (or trade-weighted ROW exchange rate index that excludes China) is constructed using exchange rates from the IMF's IFS database and annual US trade weights constructed from the USITC trade data. To control for changes in the production costs abroad in the PT regressions, I construct the trade-weighted PPI inflation abroad (or in the ROW) by using the IFS PPI data and the USITC trade weights. For both trade-weighted indices (PPI inflation and exchange rate), I use the one-year lag of the import weights to ensure that these indices are not biased by a contemporaneous correlation between the volume of trade and other macro variables. ${ }^{10}$

\footnotetext{
${ }^{10}$ The trade-weighted arithmetic average of global PPI inflation is sensitive to hyperinflation. Thus, the trade-weighted median PPI inflation is used in the analysis below.
} 


$$
\begin{aligned}
\Delta e_{U S D / R O W_{t}} & =\sum_{\text {all } j \neq \text { China }} w_{j, t} \Delta e_{U S D / C U R_{j, t}} \\
w_{j, t} & =\frac{{\text { Imports from } \mathrm{j}_{t-1}}_{\text {World Imports }}-\text { Imports from China } \text { Im-1 }_{t-1}}{\text { Imporits }}
\end{aligned}
$$

Three indices of commodity prices are added as controls. In the main specification, the overall Standard \& Poor's Goldman Sachs Commodity Index (GSCI) is used to control for changes in commodity prices. This index tracks the investment performance (measured in USD) in the commodity markets and is calculated on a global production-weighted basis of all principal commodities that are traded on the markets. Two sub-indices, the GSCI "Energy Commodity" and the GSCI "Metal Prices", are also used.

Lastly, as a measure of sectoral economic activity, the capacity utilization from the US Census' "Survey of Plant Capacity Utilization" is included in the sample. This variable is available on a quarterly basis for 102 manufacturing and publishing sectors (up to the 6 -digit NAICS level of disaggregation).

\section{Exchange Rate Pass-Through into Import Prices}

This section documents how movements of the RMB affect the prices of Chinese goods and the overall US import price index.

As China currently accounts for nearly $30 \%$ of all US imports, price changes in Chinese goods have a sizeable direct mechanical impact on the overall US import index. Thus, the RMB directly affects the US IPI if the prices of Chinese goods react to the RMB. Figure 2 relates the evolution of the RMB-USD exchange rate (right axis in RMB/USD) to the US import price index of all goods originating from China (left axis). The figure starts in December 2003, as the BLS reports a separate import price index for goods originating from China starting on that date. The first salient feature of the data is that the prices of Chinese goods have not kept up with the general inflation in the US. Although the US PPI index was more than $20 \%$ higher at the end of the sample in mid-2010 than it was in December 2003, the prices of the Chinese imports were roughly at their 2003 level in 2010. The second salient feature of the data is that the Chinese import prices only trended upward during early 2008. During the same time, the pace of the RMB appreciation was the highest. Also at other times, it seems that the increase in the Chinese import price index tended to have the most positive slope when the rate of RMB appreciation was the highest.

Figure 3 examines this relationship between the RMB and the prices of Chinese imports more closely by relating the 6 -month cumulative change in the RMB exchange rate (a positive value implies an RMB appreciation) to the 6 -month cumulative change in the Chinese import price index. There is a strong positive association between the value of the RMB and the prices of Chinese goods in the US, with the slope being estimated as significantly positive at 0.55 . Kim et al. (2011) examine the pass-through rate of the RMB into individual goods using a micro data set of import prices that the BLS uses to calculate 
the Chinese import price index displayed in Figures 2 and 3 (see Gopinath and Rigobon (2008) for a description of this data set). Kim et al.'s (2011) main conclusion is that at horizons of 12 months or longer, the PT of the RMB is high and is estimated at up to 0.8.

How does the RMB affect the general US import price level? In addition to the direct effect via the prices of Chinese goods, the RMB also indirectly affects the US IPI, as the prices of imported goods from other destinations also react to the prices of Chinese imports. Bergin and Feenstra (2009) and Pennings (2011) analyze this rate of "cross-currency passthrough" (that is, the rate at which for example Japanese import prices react to fluctuations in the RMB) and uncover a strong co-movement of prices to exchange rates other than the one that the product is from. Similarly, Itskhoki and Gopinath (2011) directly document that firms react to their competitors' prices.

China is the world's largest exporter, and if the RMB appreciates, this increase affects the equilibrium prices charged by other countries exporting to the United States. As a result, an RMB appreciation leads to an overall pass-through rate of the RMB into the US import price index that can be substantially larger than the accounting component alone. Thus, the analysis in this section now examines the RMB's overall effect on the US IPI rather than on only Chinese import prices.

Table 1 introduces the methodology of this paper and documents the effect of changes in the RMB on the overall US import price index (IPI). The structure of Table 1 is as follows. The estimation presented in columns (1) to (4) document the problem of the endogeneity of the Chinese appreciation, when the estimation uses only the appreciation period after June 2005. The next two specifications in columns (5) and (6) present a controlling strategy, and the last two specifications present the pass-through specifications of the RMB on the filtered import price indices. Columns (1) to (4) present the results of the fixed effects panel estimations evaluating the n-month(s) cumulative change in the US IPI at the 5-digit level of disaggregation.

Column (1) presents a pass-through estimation measuring the rate at which the sectoral IPI reacts to changes in the RMB. The estimated specification is

$$
\Delta I P I_{t-n, j}=\alpha_{j}+\beta_{R M B, j} \Delta e_{U S D / R M B_{t-n}}+\gamma_{j}^{\prime} X_{t-n}+\epsilon_{j, t-n},
$$

where only the rate of producer price inflation in China is added as a control to measure changes in the cost of production faced by Chinese firms. The specification is estimated in the sample from June 2005 onwards. The specification presented in Column (1) is estimated at the 3 -month horizon $(n=3)$. The coefficient of the RMB is estimated at 0.54 , implying that a $1 \%$ increase in the USD/RMB exchange rate leads to an increase in the US IPI of $0.54 \%$. This seems quite large given that in the sample included in Column (1), China accounts for $22 \%$ of all imports on average. Consequently, only a large rate of "crosscurrency" PT could explain the sizeable effect of the RMB on the US IPI. For example, even if the PT rate of the RMB on Chinese goods is equal to 0.8 (i.e., the maximum $\mathrm{PT}$ estimated in Kim et al. (2011)), the accounting component explains only $0.176(=22 \% * 0.8)$ of the total effect of 0.64 of the RMB on the IPI. When the same specification is estimated 
at the 6-month horizon, the PT rate is estimated even higher at 0.64 , thus posing an even bigger question mark as to whether China's causal effect on the US import price level could really be that large.

In the estimations of Columns (3) and (4), the set of controls is enlarged, and the specification includes the ROW exchange rate, the PPI inflation rate in all of the trade partners (trade-weighted) and the Goldman Sachs Commodity Index. For all of the variables, the cumulative changes at the n-month horizon are constructed, and the following fixed effects panel specification is estimated.

$$
\Delta I P I_{t-n, j}=\alpha_{j}+\beta_{R M B, j} \Delta e_{U S D / R M B_{t-n}}+\beta_{R O W, j} \Delta e_{U S D / R O W_{t-n}}+\gamma_{j}^{\prime} X_{t-n}+\epsilon_{j, t-n}
$$

Including these controls dramatically changes the coefficient of the RMB. At the 3-month horizon, it decreases from 0.54 to 0.25 (see Columns (1) and (3), respectively), and at the 6-month horizon, the coefficient drops from 0.64 to 0.31 (see Columns (2) and (4), respectively). It is noteworthy that in the joint estimation of columns (3) and (4), the effect of the ROW exchange rate is surprisingly small. The coefficient of the latter variable is estimated at 0.072 at the 3 -month horizon and at only 0.027 (not significant at the $10 \%$ level) at the 6 -month horizon. This result stands in stark contrast to almost all of the findings in the current literature (see, for example, Goldberg and Campa (2010)) and suggests that these estimations are mis-specified.

To rationalize the estimation results in the first four specifications of Table 1, I next follow the methodology described in Section 2 and use the information from the decade during which the RMB was fixed to the USD. In column (5), the sample includes the time period from January 1995 to June 2005. The specification includes changes in the US IPI as the dependent variable and changes in the ROW exchange rate as the independent variable. In contrast to the specifications in the samples including the time period after June 2005 (the post-2005 sample from here on), the effect of the ROW exchange rate on the US IPI is sizeable and is estimated to be 0.15 and 0.24 at the 3 - and 6-month horizons, respectively (see Columns (5) and (7)). This result is much more consistent with the findings of the current literature than the specifications in Columns (3) and (4).

The last two specifications of Table 1 present the effect of the RMB on the US IPI after the effect of the ROW exchange rate is netted out. The methodology is as is discussed in Section 2: I use the pre-2005 coefficients from Columns (5) and (7), together with the realizations of the ROW exchange rate after 2005 to subtract the ROW exchange rate's effect in the post-2005 period from the actual IPI realizations.

In Columns (7) and (8), I estimate the effect of the RMB on the IPI after filtering out the effects of the other controls. The 3 -month coefficient in Column (7) is estimated to be 0.292 . Taking the PT rate of 0.8 for individual Chinese goods from Kim et al. (2011) and the Chinese import share, this finding implies that the direct accounting component explains $0.176(0.8 * 0.22)$, and the indirect response of non-Chinese prices explains the remaining 0.126 of the total response of the IPI to the RMB. The last specification of 
Table 1 repeats this specification at the 6 -month horizon and reveals a much higher rate of PT (equal to 0.47 ).

Figure 4 documents the cumulative pass-through rate estimated at various horizons for the changes in the RMB (black solid line, surrounded by two dashed lines representing the $95 \%$ confidence interval (CI)). The pass-through coefficients displayed in this figure are computed in the same manner as those computed for specifications (6) and (8), with the effect of the ROW exchange rate being netted out from a specifications of the type presented in columns (5) and (7). Each point in Figure 4 presents the rate of conditional pass-through resulting from a fixed effects panel regression of the "cumulative import price change over the last n months, net of ROW exchange rate effect" as the dependent variable on the "cumulative RMB exchange rate change over the last $\mathrm{n}$ months" as independent variable, with $\mathrm{n}$ varying from one to 24 . The response of the IPI to the RMB follows a hump-shaped pattern, with the coefficient increasing up to 0.47 at the 7 -month horizon and decreasing to 0.16 in the long run.

Overall, the results of this section demonstrate that the effects of the RMB appreciation on US import prices are surprisingly strong. How can these results be explained? The passthrough rate might be different for the case of the RMB revaluation compare to movements of other currencies, as the path of the RMB predictably moved in only one direction (this was also widely expected as forward contracts from the 2005 to 2008 period reveal). An exporter from a country with a freely floating rate might only have responded to large shocks as exchange rate volatility reduces the incentives to adjust prices. In turn, the effect of exchange rate volatility is due to the implicit option value of waiting to determine how the exchange rate evolves. However, Chinese exporters could have predicted that every appreciation was permanent and was likely to be succeeded by future appreciations. ${ }^{11}$

Moreover, given that the origin of the shocks that caused the RMB to appreciate during the 2005-to-2008 period are different from market-determined exchange rate movements, there are strong reasons to believe that the rate of pass-through following these appreciations differs from the rate of pass-through following market-determined exchange rate movements. $^{12}$

Furthermore, one could also expect the rate of pass-through for China to differ from that of the rest of the world because sectors are heterogeneous with regard to the rate of pass-through and because the composition of Chinese exports differs starkly from that of other nations. ${ }^{13}$ Section 6 below investigates this possibility in more detail.

\footnotetext{
${ }^{11}$ Froot and Klemperer (1989) show that temporary exchange rate changes may not pass through to import prices, whereas Baum et al. (2001) demonstrate that imperfect information on the permanent component of changes in the exchange rate affects the relationships among the exchange rate volatility, prices, and profitability. Also Taylor's (2000) analysis of the relationship between the degree of pass-through and the inflationary environment makes a case for the importance of a firm's expectation regarding the future evolution of desired prices when responding to exchange rate changes.

${ }^{12}$ Burstein et al. (2003 and 2005) study the pass-through rate following large depreciations, such as the one following the Argentinean debt crisis, with the prior that the rate of pass-through following a crisis could be different from the rate of pass-through after day-to-day exchange rate movements during calm market periods.

${ }^{13}$ Goldberg and Tille (2008) and Gopinath et al. (2010a) demonstrate that the denomination of imports
} 


\section{$5 \quad$ Pass-Through Into Producer Prices}

The previous section introduced the empirical approach of this study and demonstrated that the effect of the RMB on US import prices is sizeable. This section examines to what extent these IPI movements are passed through into domestic producer prices. To the best of the author's knowledge, this study is the first to quantify this effect. ${ }^{14}$

Table 2 first documents that the OLS relation between import and producer prices is substantially stronger after 2005. The table subsequently shows that the stronger relation between IPI and PPI in the post-2005 period is due to the RMB appreciation. Columns (1) and (2) present the OLS relationship between the import and producer prices. In Column (1), the panel includes 418 6-digit NAICS sectors from January 1995 to June 2005. The coefficient of the IPI is estimated to be 0.095 (that is, a $10 \%$ increases in the import prices implies only a $0.95 \%$ increase in the producer prices) and is significant. In contrast, the same estimation in the sample of Column (2), which includes a sample starting after June 2005, results in a coefficient of 0.349 (that is, the coefficient is well over three times as large as the previously estimated coefficient). Columns (3) and (4) demonstrate that this increasing correlation between the import and producer prices is also visible when conditioning on the ROW exchange rate, PPI inflation abroad, and global commodity prices.

Is the RMB appreciation responsible for the increase in the correlation of the import and producer price inflation? From Column (5) onward, Table 2 presents two-stage least square estimation (2SLS) results that relate the changes in the RMB to changes in the US IPI and that second examine how these RMB-induced IPI movements affect the sectoral PPI. In the 2SLS estimation of Column (5), the sample includes the post-2005 period, and the instrumented change in the filtered sectoral IPI is the only independent variable. The latter variable is the first-stage projection with the change in the filtered IPI as dependent and the change in the RMB as independent variable. Because this first-stage projection is identical to the estimation presented in Column (7) of Table 1, this projection is not reported.

This methodology reveals that the RMB-induced movements of import prices have a strong overall impact on the prices charged by US firms. The coefficient is estimated to be 0.800 , which, given the corresponding first-stage coefficient of 0.292 (see Column 7 in Table 1), implies that a $10 \%$ appreciation in the RMB increases import prices by $2.92 \%$ and producer prices by $2.336 \%(=0.8 * 2.92 \%)$. For the 2 SLS presented in Column $(5)$,

is of major consequence for the pass-through rate. Against this backdrop, it would be be worthwhile to investigate whether Chinese imports tend to be dollar-denominated more often than imports from other origins.

${ }^{14}$ Nakamura and Steinson (2010) document that the pass-through coefficients estimated using micro data may be biased, as many price changes occur if firms discontinue their existing product lines and replace them with slightly modified ones. The PPI analyzed in this section are less affected by this problem (although they might not be altogether free of it), as the BLS spends substantially more resources on estimating quality changes during product replacement for the PPI data as is the case for the IPI data. 
the first-stage estimation is identical to the estimation presented in Column (7) of Table 1 and thus is not reported. However, the bottom of Table 2 reports additional statistics of the 2SLS estimation. To test for weak identification, the bottom of Table 1 reports the p-value associated with Anderson's canonical correlation LR statistic and the lowest Stock and Yogo (2005) critical value for the maximum IV bias/size that can be rejected (the $10 \%$ level can always be rejected, which is the lowest value for which Stock and Yogo (2005) compile a critical value).

A limitation of the estimation presented in Column (5) is that it is not possible to directly control for the effect of the ROW exchange rate on the PPI, as the inclusion of this variable into the second-stage estimation necessitates the inclusion of this variable into the first-stage estimation. Therefore, attempting to control for the effect of the ROW exchange rate on the PPI invalidates the identification strategy proposed in Section 2 above. However, it is possible to also filter out the effects of the ROW exchange rate on the PPI index by using the pre-2005 sample, which is performed in the left sub-column of specification (6). In this specification, the relation between the ROW exchange rate and US PP-inflation is estimated. The resulting relation is then predicted for the post-2005 sample, and this predicted effect is then netted out from the post-2005 PP-inflation. The specification in Column (6B) examines the effects of the RMB-induced movements of import prices on the filtered producer price changes in the 2SLS specification and uncovers a coefficient of 0.712 , which is not too different from the coefficient found in Column (5) of Table 2. Because thefirst stage estimation relating the RMB to import prices is again identical to the estimation in Column 7 of Table 1, I do not report this result.

At the 3-month horizon, much of the increase in the correlation between the importer and producer prices can be attributed to the beginning of the RMB appreciation in mid2005. To gauge whether the results of Columns 1 to 4 are representative for other horizons, I first reproduce the analysis at the 6-month horizon. Specifications (7) and (8) report that also at the 6-months horizon, the effect of the IPI on the PPI is much more pronounced in the post-2005 sample than before the appreciation period. Specifications (9), (10), and (11) then repeat the IV strategy and show that at the 6-month horizon, the RMB appreciation has a pronounced effect on the PPI before and after the effect of the ROW exchange rate is filtered.

Figure 4 displays the rate at which the RMB-induced IPI movements affect the PPI. Each of the 24 data points in this figure corresponds to an estimation along the lines of Columns $6 \mathrm{a}$ and $6 \mathrm{~b}$ and $10 \mathrm{a}$ and $10 \mathrm{~b}$ in Table 2, with a horizon ranging from 1 to 24 months. That is, for each of these data points, a 2SLS estimation relating the filtered PPI change to the filtered and instrumented IPI change is estimated in the post-2005 period. Both the IPI and the PPI have previously been filtered by the effect of the ROW exchange rate in the pre-2005 period. Furthermore, the upper and lower boundaries of the $95 \%$ confidence interval for each coefficient are displayed.

At most horizons (except the 1-month horizon and the horizons over 20 months), the coefficient is stable throughout time and the 2SLS coefficient is equal to roughly 0.7. There 
is no large difference when one also filters out the effect of the ROW exchange rate on the PPI (black line)or not (grey line).

At most horizons (expect the 1-month and at horizons over 20 months), the coefficient is stable throughout time and estimated at roughly 0.7 for the 2SLS estimations in contrast to roughly 0.6 for the OLS Estimations.

I next turn to the first part of the robustness analysis, which focuses mostly on the variations of the estimated specifications (the next section examines whether the results are driven by certain sub-groups of sectors). Because the analysis in Figure 5 suggests that the pass-through coefficient is comparable for horizons between 3 and 18 months, I continue with a robustness analysis at the 6-month horizon in Table 3. Throughout the table, the first-stage results are reported in the lower Panel A, and the second-stage results are reported in the upper Panel B. In all of the first-stage specifications, the dependent variable is the change in the sector's IPI, which is filtered for the effect of the ROW exchange rate. In all of the second-stage estimations, the dependent variable is the change in the sector's PPI, which is also filtered for the effect of the ROW exchange rate.

First, it is not clear a priory that the included measures of PPI inflation abroad is a relevant cost measure, as it might simply measure the global inflationary pressure and thus be correlated with the US IPI and PPI. For that reason, Column (1) excludes this variable.

Second, if PPI abroad is a measure of the changes in production costs, the response of Chinese prices to the PPI inflation at home might be stronger than the price responses of other trade partners to their local cost inflation. In Column (2), instead of controlling for the trade-weighted global PPI inflation, the estimation includes the Chinese PPI inflation rate. This variable is not included as a baseline control because the variable is available at a monthly frequency. However, Statistics China only reports a 12-month rolling average inflation rate. Because it is arithmetically impossible to construct a 1-month series of price changes from a 12-month rolling average inflation rate, the 6-month cumulative change examined in Column (2) is constructed from the following formula:

$$
\Delta P P I_{\text {China }, t, t-1}=\frac{\Delta P P I_{\text {China }, t, t-12}}{12}+\left[\Delta P P I_{\text {China }, t, t-12}-\Delta P P I_{\text {China }, t-1, t-13}\right] .
$$

In Column (2), the dependent variable is the monthly change in the producer price at the 5-digit NAICS level, and the fixed effects panel estimations include a trend.

In the pass-through regressions estimated in the literature, scholars commonly include the rate of domestic producer price inflation in the importing country as a general measure of the importer's price developments. As the rate of US producer price inflation is the dependent variable in the specifications estimated in this paper, including this variable in the first-stage estimation would obviously be spurious. However, it is still worthwhile to examine how the inclusion of a measure of U.S. sectoral economic activity influences the results. Therefore, Column (3) includes the sectoral capacity utilization from the US Census "Survey of Plant Capacity Utilization" in the estimation. 
The baseline specifications control for the overall Standard \& Poor's Goldman Sachs Commodity Index as a proxy for the effect of commodity prices on US producer and importer prices. This index tracks the investment performance of all of the principal commodities that are traded in the commodity markets. Certain subcomponents of this index, particularly crude oil and other energy commodities, may disproportionately influence prices. Thus, instead of the overall index, the estimation in Column (4) includes two commodity price sub-indices: the GSCI "Energy Commodity" and the GSCI "Metal Prices." In contrast, the estimation in Column (5) does not include a commodity index.

Import prices might mean-revert and it could also be the case that import prices have a lagged effect on producer prices. Column (6) adds two 6-month lags to the import price (i.e., the change in the price from -12 to -6 months and from -18 to -13 months) to the estimation with rather inconclusive results. The first-stage estimations imply that import prices meanrevert. In contrast, the second-stage estimation implies that the effect of import prices on producer prices first diminishes (from -12 to -6 months) and then increases (from -18 to -13 months).

The last few columns of Table 3 examine whether the matching mechanism of the BLS import price indices to the 5-digit NAICS sectors (see section 3) affects the results. In the baseline specification, I restrict the analysis to 5-digit NAICS sectors to which an import price index at the 4-digit NAICS level of disaggregation can be allocated. In turn, all of the 5-digit import prices are allocated to the 6-digit PPI sector. In addition, Column (7) uses those import prices to which a 3- or 2-digit NAICS IPI can be allocated.

Throughout the robustness tests estimated in Table 3, the estimated coefficients for the effect of the RMB on the US IPI range from 0.53 to 0.85 , which is not far from the baseline estimate of 0.69 (see the last specification of Table 2). Furthermore, the firststage coefficients display limited variation (from 0.36 to 0.78 , as opposed to the baseline specification of 0.47 , which is displayed in Column (8) of Table 1) and the estimation is well identified, as demonstrated by the weak identification tests displayed at the bottom of Table 3 .

\section{Heterogeneous Pass-through Rates Across Sectors}

Thus far, the analysis has shown that the changes in the RMB-dollar exchange rate and the associated import price movements significantly affect US producer prices. Next, I explore in greater depth the determinants of the rate of pass-through into the import and producer prices at the sectoral level.

In this section, I relate the pass-through rate to various sector characteristics, such as labor intensity, elasticity of demand, importance of traded intermediate goods in production, and openness to trade. Doing so helps to clarify the microeconomics explaining how the exchange rate ultimately affects inflationary pressure. Moreover, these exercises help 
to refine the simulations of the inflationary effect of a potential appreciation of the RMB. These simulations are undertaken in Section 7 below.

Heterogeneity in the responses of producer prices to exchange rate changes may result from differences in the responses of import prices to the exchange rate or from differences in the responses of producer prices to import prices. Consequently, the analysis proceeds with two different sets of empirical tests. In the first set of tests, reduced-form estimations that directly relate the RMB changes to the changes in producer and importer prices are presented for various subsamples. In the second set of tests, the results of the 2SLS estimation for the various subsamples are presented.

The structure of Table 5 is the following. It presents the results of four different direct pass-through regressions in Panels A, B, C, and D and two 2SLS estimations in Panels E and F. In Panels $\mathrm{A}$ and $\mathrm{B}$, the dependent variable is the 3 -month change in the producer price. In Panel A, the only independent (in addition to fixed effects and a trend) variable is the contemporaneous 3-month change in the exchange rate. In Panel B, a lag of the latter variable is added to the estimation. In Panels $\mathrm{C}$ and $\mathrm{D}$, the dependent variable is the 6month change in the producer price. In Panel $\mathrm{C}$, the only independent (in addition to fixed effects and a trend) variable is the contemporaneous 6-month change in the exchange rate. In Panel D, a lag of the latter variable is added to the estimation. Finally, the estimations in Panels E and F reproduce the 2SLS presented in Tables 2 and 4 at the 3-month and 6-month horizons. For these six types of pass-through regressions, the sample is always split by a sector-specific characteristic.

The sector characteristics used to split up the sample must fulfill two requirements. First, each characteristic needs to be stable throughout time such that the sample included in each of the columns in Table 5 is stable throughout time. This stability is important because, for example, the changes in labor intensity could be driven by exchange rate movements. Therefore, instability in the sample split would cause the sample composition to be correlated with the dependent variable.

Second, these characteristics should also on average not be affected by the demand conditions in China or the US during the period studied in this paper. An external measure of an industry's intrinsic characteristics is needed to split the sample. This variable should reflect the fact that there are technological reasons to use more labor or more traded inputs in some industries than in other industries. Therefore, I use only US industry information before December 2003 to construct these measures. I implicitly assume that in the United States in the years leading up to 2004, if the production of one good requires relatively more inputs or labor than the production of another good, the same is true at the current juncture.

An obvious candidate for splitting the sample is the import share of China, which is defined as the pre-2003 market share of Chinese goods as a percent of all of the imports in sector $\mathrm{j}$.

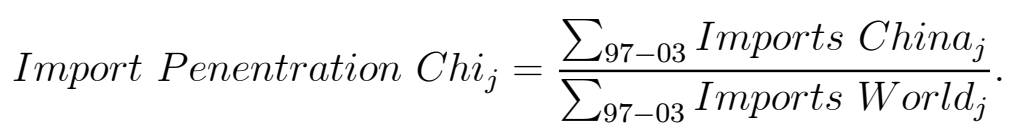


Columns (1) and (2) in Panels A and B indicate that the response of import prices to the movements of the RMB is more pronounced in the sectors with higher shares of Chinese imports. However, the difference is much smaller than one would expect. For example, the PT rate in the sample with a higher-than-median import share is equal to 0.44 , whereas the $\mathrm{PT}$ rate is equal to 0.37 in the other half of the sample.

Intriguingly, the reduced-form estimation, which estimates the effect on producer prices (see Panels C and D), and the 2SLS estimations (Panels E and F) document that the response of producer prices is actually large in sectors with less Chinese import penetration. The reason for this could be that China's imports are concentrated in certain types of sectors that are characterized by a low degree of pass-through.

For example, in Columns (3) and (4), the sample is split by the average labor intensity in the US, which is taken from Auer and Fischer (2010) and defined as the ratio of the expenditures on labor divided by the expenditures on capital. Auer and Fischer use the information from the BLS annual survey of manufacturing to calculate the expenditures on capital. The researchers also average the labor intensity throughout time such that the resulting variable does not vary within a NAICS 5 - or 6 -digit sector.

$$
\text { Labor Intensity } \text { In }_{j}=\frac{\sum_{97-03} U S \text { Labor Expenditures } \text { Ex }_{j}}{\sum_{97-03} \text { US Capital Expenditures }}
$$

All four reduced-form estimations in Panels A to D reveal that the rate of pass-through into producer prices is higher in the sectors with relatively more capital expenditures relative to labor expenditures. For example, although the 3 -month rate of pass-through (see Panel A) is 0.32 in the sample of labor-intensive sectors, it is estimated to be 0.38 for the rest of the sample. These economic magnitudes are roughly confirmed by the estimations including lags at the 6-month horizon.

In Columns (5) and (6), the sample is split by the elasticity of demand, which is taken from Broda and Weinstein (2006). Unexpectedly, the differences in the import pricing responses between these types of sectors are minimal. However, the response of producer prices to the RMB (see Panels $\mathrm{C}$ and D) and the 2SLS effect of the IPI on the PPI (E \& $\mathrm{F})$ is larger in the sectors with elastic demand.

Columns (7) and (8) document that the price of imported intermediate goods is a key channel through which the RMB affects US domestic prices. In Columns (7) and (8), the sample is split by input intensity, which is defined based on Schott (2004). In Schott (2004), trade flows at the 10-digit Harmonized System (HS) that contain words such as "onput", "part", and "intermediates" in the good description are classified as containing intermediate goods. The resulting dummy is subsequently aggregated to the 6-digit NAICS level taking into account the weight of each 10-digit HS good in the respective 6-digit NAICS sector. The resulting variable measures the volume-weighted fraction of the 10-digit HS goods within a 6-digit NAICS sector that includes intermediate goods. Thus, the variable can take any value between 0 and 1 . 
The estimation in Column (7) includes the sectors that do not contain any intermediate goods (i.e., these sectors contain only final consumption goods. The sample is split up in this way as more than $50 \%$ of the observations do not contain any intermediate goods), and the estimation in Column (8) includes only the sectors with at least some intermediate goods. The rate of pass-through into import prices is comparable in Columns (7) and (8). However, the response of producer prices in Panels C and D is much greater in the intermediate goods sectors. Thus, the 2SLS coefficients in Panels E and F that measure the effect of an import price increase on producer prices are larger in the group of intermediate goods sectors.

The sectors also differ substantially with respect to the many technological characteristics that determine whether the sector is more or less open to trade in equilibrium. In turn, this quality might affect the equilibrium pass-through rate. To summarize these characteristics, I construct a measure of trade openness to the rest of the world that is defined by how much of the non-Chinese consumption in a sector (i.e., total US consumption minus the US imports from China) originates from the rest of the world (i.e., total imports minus the imports from China). Thus, the sample in Columns (9) and (10) is split by

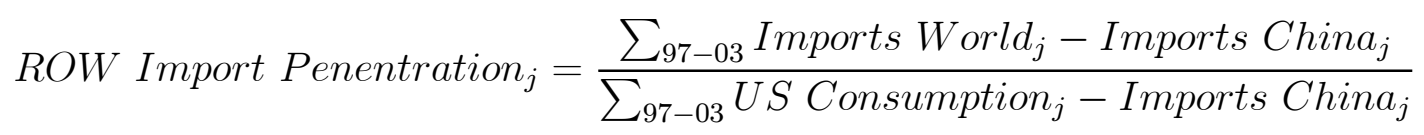

Columns (9) and (10) document that the pass-through into producer prices is somewhat higher in the sectors that are less open to the ROW than in the other sectors.

Overall, Table 5 presents evidence that the rate of pass-through differs considerably among sectors with different characteristics. This finding suggests the mechanisms through which the RMB affects US prices. One channel is the importance of the intermediate goods used in production. A second channel is the demand parameter, approximated here by Broda and Weinstein's (2006) demand elasticities.

\section{The Total Effect of the Appreciation}

I use the findings from the above analysis to estimate the inflationary impulse of an RMB appreciation on the US producer price index. For these predictions, I combine the previous findings and account for the fact that the pass-through is heterogeneous along the dimension of input and labor intensity and along the dimension of demand elasticity.

The simulations account for the fact that exchange rate changes might affect producer prices only with a lag and that the producer prices themselves have an autocorrelation structure. Each sectoral pass-through rate is multiplied by the sector's weight in the official US PPI. Because the total weight of the sectors included in this study is less than $30 \%$ of the PPI, the magnitude of the overall effects as a percentage of the PPI is approximately a third of what the coefficients in the analysis suggest.

Figure 5 presents the size of the total relative price shock in terms of the US PPI annual inflation rate. The red solid line corresponds to a scenario in which the RMB 
appreciates for 10 months at a rate of $2.5 \%$ per month. That is, the red solid line addresses the following counterfactual. What is the difference of the annual PPI inflation rate if the RMB appreciates by $2.5 \%$ per month and the annual PPI inflation rate if the RMB stays entirely unchanged. This predicted impact on the US PPI peaks at approximately 4 percentage points near the end of the 10-month appreciation window.

Figure 5 also presents a second scenario, where the RMB appreciates at $1 \%$ per month for 25 months. In this case, the total impact on the PPI does not exceed positive 2 percentage points. However, the impact is also more long-lived. That is, the total shock on the US producer price index exceeds 1 percentage point for a period of nearly two years.

Figure 5 documents that an RMB revaluation would result in relative price shocks to together amount to a substantial impulse on the aggregate PPI. On theoretical grounds, however, it is not clear that such relative price shocks affect the equilibrium inflation because price decreases by firms experiencing substantial import competition could be offset by price hikes in other parts of the economy. Ball and Mankiw (1995) note that in this context, one needs to evaluate the distribution of price shocks. Ball and Mankiw argue that in the presence of menu costs, firms adapt their prices to large external shocks but not to small shocks. Therefore, large shocks have disproportionate effects on the price level, and aggregate inflation depends on the distribution of relative-price changes such that inflation rises if the distribution is skewed to the right and falls if the distribution is skewed to the left.

Figure 6 examines the sectoral distribution of the price shocks that result from the RMB appreciation. The figure reports two univariate kernel density estimates when the RMB appreciates by $25 \%$ over either 10 months (red solid line) or over 25 months (orange dashed line). The size of the monthly price shock in each sector is measured as a percentage and is displayed on the horizontal axis, while the density (in sector-months observations) is displayed on the vertical axis. Figure 8 covers the 30 months after the appreciation.

Figure 6 reveals that a rapid appreciation (2.5\% per month) would lead to a strongly right-skewed distribution of relative price shocks. Thus, the considerations raised along the line of Ball and Mankiw (1995) imply that at this pace, an RMB-revaluation is likely to also affect the U.S. aggregate PPI inflation.

Interestingly, the effect on the distribution of relative price shocks is much more contained when the RMB increases at $1 \%$ per month because the mean-reverting pattern of sectoral prices starts to become relevant approximately 9 months after the appreciation (and more thereafter). As the sectors that are most affected by the appreciation are also the ones in which the mean-reversion has the strongest effect, the slower rate of appreciation leads to less extreme sectoral price shocks.

The above analysis concentrates on the price response to exchange-rate movements. Before concluding, I briefly investigate the response of import volume to an exchange rate appreciation. Of course, given the amount of attention that the "global imbalances" topic 
has received in the press, numerous studies have already attempted this exercise (see the various studies undertaken and summarized in Claessens et al. (2010)). However, the data set in this study contains only the sectors for which information on prices is available. Thus, it is worthwhile to evaluate whether the quantity response in this sample is comparable with the findings of the existing literature.

Figure 7 presents the cumulative response of the volume of imports from China (changes in the natural logarithm of dollar import volume) at various horizons. The coefficients displayed in this figure are computed in the following manner. For each n-months horizon, Figure 7 presents the change in the "Cumulative Change of $\$$ Import Volume over the last N Months" as the dependent variable and the "Cumulative Exchange Rate Change over the last $\mathrm{N}$ Months" as the independent variable, where $\mathrm{N}$ ranges from 1 to 36 . The associated 95\% CI for each horizon is also displayed. There is no response of import volume until the 16-month horizon. Thereafter, the response becomes increasingly negative, and the elasticity gradually increases in magnitude to approximately -5 after two and a half years. Thereafter, the elasticity stays roughly constant at this level.

\section{Conclusion}

The course of US inflation over the next several years may be closely intertwined with the resolution of global imbalances. The rise of cheap imports from China was a major contributor to the low-inflation environment during the last decade. For the US, Auer and Fischer (2010) show that the rise of import competition from low-wage countries has decreased US inflationary pressure by approximately half a percentage point during the last decade. The latter study also documents that this effect was primarily due to the rise of China.

If an appreciation of the RMB is aimed at restoring a balanced US-Chinese current account and is successful in doing so, the disinflationary effect will likely be reversed. The analysis of this paper quantifies the relative price shock resulting from an RMB revaluation using a estimation technique that takes into account that the Chinese Government followed other exchange rates when the RMB appreciated, then investigates the response of import prices to the RMB/dollar exchange rate and, in a third step, estimates the resulting response of US producer prices.

This analysis finds much more pronounced effects than is commonly assumed. For example, in a sample spanning up to 418 US manufacturing sectors, the rates of passthrough of import prices into US producer prices is estimated to equal 0.7 on average. Simulations that take into account that the rate of pass-through is heterogeneous across sectors, that the timing of the pass-through into producer prices matters, and that producer prices have an autocorrelation structure reveal that a substantial revaluation of the RMB would result in a substantial upward impulse on the prices of goods traded in the US.

Researchers and policymakers are primarily worried that external adjustments from the US could create economic problems outside of the US (see, for example, Kamin et al. 
(2007)). I show that the US economy could actually be adversely affected if the external adjustment is achieved via a drastic RMB revaluation. Therefore, US policymakers must consider these possibilities when deciding their course of action regarding their trade policy with China.

\section{References}

[1] Atkeson, Andrew and Ariel Burstein, "Pricing to Market, Trade Costs, and International Relative Prices,", American Economic Review, December 2008.

[2] Auer, Raphael A. and Thomas Chaney. (2007). "How do the Prices of Different Goods Respond to Exchange Rate Shocks? A Model of Quality Pricing-to-Market." Mimeo, University of Chicago.

[3] _ _ (2009). "Exchange Rate Pass-Through in a Competitive Model of Pricing-toMarket." Journal of Money, Credit and Banking, 41 (s1): 151-175.

[4] Auer, R. A. and A. M. Fischer, 2010. The effect of low wage import competition on U.S. inflationary pressure, Journal of Monetary Economics 57(4), 491-503.

[5] Auer, R. A., K. Degen and A. M. Fischer, 2010. "Globalization and Inflation in Europe" Mimeo Swiss National Bank

[6] Bacchetta, Philippe and Eric van Wincoop, 2003. "Why Do Consumer Prices React Less Than Import Prices to Exchange Rates?," Journal of the European Economic Association, MIT Press, vol. 1(2-3), pages 662-670, 04/05.

[7] Bailliu, Jeannine, and Eiji FujII, "Exchange Rate Pass Through and the Inflation Environment in Industrialized Countries: An Empirical Investigation," Bank of Canada working paper 2004-21 (2004).

[8] BALl, L. and N.G. MAnkiw, (1995 ). "Relative-price changes as aggregate supply shocks", Quarterly Journal of Economics 110 (1) (1995), pp. 163-193.

[9] Baum, C. F., Caglayan, M. and Barkloulas, J. T. (2001), "Exchange Rate Uncertainty and Firm Profitability", Journal of Macroeconomics, 23, 565-576.

[10] Bergin, Paul R. and Robert Feenstra. 2001 P.R. Bergin and R.C. Feenstra, Pricingto-market, staggered contracts, and real exchange rate persistence. Journal of International Economics, 54 (2001), pp. 333-359.

[11] _- "Pass-through of Exchange Rates and Competition Between Floaters and Fixers, 2008. Journal of Money Credit and Banking 41 (1), 35-70.

[12] Bernard, A. B., J. B. Jensen, and P. K. Schott, 2006 . Survival of the best fit: exposure to low-wage countries and the (uneven) growth of U.S. manufacturing plants. Journal of International Economics 68(1), 219-237. 
[13] Bosworth, B (2004). Valuing the renminbi. Paper presented at the Tokyo Club Research Meeting, 9-10 February.

[14] Broda, Christian, and David Weinstein. (2006). "Globalization and the Gains from Variety." The Quarterly Journal of Economics, 121 (2): 541-585.

[15] Bugamelli, M., S. Fabiani, and E. Sette, 2010. The pro-competitive effect of imports from China: an analysis of firm level price data, Temi di discussione 737, Bank of Italy.

[16] Bureau of Labor Statistics (2010)., BLS Handbook of Methods, Chapter 14 Producer Prices, Background (accessed online $201011 \quad 10$ at: http://www.bls.gov/opub/hom/homch14_a.htm).

[17] Burstein, Ariel and N. Jaimovich (2009), "Understanding Movements in Aggregate and Product-Level Real Exchange Rates," mimeo UCLA.

[18] Burstein, Ariel, Joao Neves, and Sergio Rebelo, "Distribution Costs and Real Exchange Rate Dynamics during Exchange Rate Based Stabilizations," Journal of Monetary Economics 50:6 (September 2003), 1189-1214.

[19] Burstein, Ariel, Martin Eichenbaum, and Sergio Rebelo, (2005) "Large Devaluations and the Real Exchange Rate," Journal of Political Economy, August 2005.

[20] __ "Modeling Exchange Rate Passthrough After Large Devaluations,", Journal of Monetary Economics, March 2007.

[21] Campa, José Manuel and Linda S. Goldberg (2005). "Exchange Rate Pass Through into Import Prices," Review of Economics and Statistics, 87:4 (2005), 679-690.

[22] Chen, Natalie, Jean Imbs and Andrew Scott "The Dynamics of Trade and Competition", Journal of International Economics, February 2009, Vol. 77(1), pp.50-62

[23] Cheung, Y, M Chinn, and E Fujil (2010), "China's Current Account and Exchange Rate", in R Feenstra and S-J Wei (eds.), China's Growing Role in World Trade, University of Chicago Press.

[24] Claessens, Stijn, Simon Evenett and Bernard Hoekman (eds.) (2010)). Rebalancing the Global Economy: A Primer for Policymaking Published 23 June 2010 BY VoxEU.ORG

[25] Cline, William R (2010). "Renminbi Undervaluation, China's Surplus, and the US Trade Deficit", Peterson Institute for International Economics Policy Brief 10-20.

[26] Corsetti, Giancarlo and Luca Dedola, "Macroeconomics of International Price Discrimination," Journal of International Economics 67 (2005), 129-156. 
[27] Corsetti, Giancarlo, Luca Dedola, and Sylvain Leduc, "Pass Through and Exchange Rate Fluctuations," manuscript, Board of Governeours of the Federal Reserve, (2004).

[28] Corsetti, Giancarlo, Pesenti Paolo, Nouriel Roubini and Credic Tille (2000). "Competitive devaluations: toward a welfare-based approach," Journal of International Economics, Elsevier, vol. 51(1), pages 217-241, June

[29] Devereux, Michael B. and Charles Engel, "Exchange Rate Pass-Through, Exchange Rate Volatility, and Exchange Rate Disconnect," Journal of Monetary Economics 49 (2002), 913-940.

[30] Dornbusch, Rudiger (1987). "Exchange Rates and Prices," The American Economic Review, Vol. 77, No. 1., pp. 93-106. March 1987.

[31] Dotsey, M. and R.G. King 2005, Implications of state-dependent pricing for dynamic macroeconomic models, Journal of Monetary Economics 52 (2005), pp. 213-242.

[32] FeinberG, Robert M (1986): “The Interaction of Foreign Exchange and Market Power Effects on German Domestic Prices". Journal of Industrial Economics, Vol. 35, No. 1, pp. $61-70$.

[33] FeinberG, Robert M (1989): "The Effects of Foreign Exchange Movements on U.S. Domestic Prices". Review of Economics and Statistics, Vol. 71, No. 3, pp. 505-11.

[34] Frankel, Jeffrey (2009), "New Estimation of China's Exchange Rate Regime", Pacific Economic Review ,14(3):346-360, August.

[35] __ (2010), "The renminbi since 2005." Colunmn, VoxEU.org, Published on 16 April $20 \overline{10}$

[36] Frankel, J. A., D. C. Parsley, and S.-J. Wei (2005): "Slow Passthrough Around the World: A New Import for Developing Countries?," NBER Working Paper 11199.

[37] Frankel, Jeffrey and Shang-Jin.Wei (2007), "Assessing China's Exchange Rate Regime", Economic Policy, 51:575-614.

[38] _ _ (2008), "Estimation of De Facto Exchange Rate Regimes: Synthesis of the Techniques for Inferring Flexibility and Basket Weights", IMF Staff Papers 55:384-416.

[39] Froot, Ken A., and Paul D. Klemperer, "Exchange Rate Pass-Through When Market Share Matters," American Economic Review 79 (1989), 637-654.

[40] Gagnon, Joseph, and Jane Ihrig, "Monetary Policy and Exchange Rate PassThrough," Board of Governors of the Federal Reserve System, International Finance discussion papers no. 704 (July 2001). 
[41] Geithner, Thimothy E. (2009), Remarks made at the Public Confirmation hearing by the US Senate Finance Committee on January 21st, 2009.

[42] Giovannini, A. (1988): "Exchange Rates and Traded Goods Prices," Journal of International Economics, (24), 45-68.

[43] Goldberg, Linda S. and José Manuel Campa (2010). "The Sensitivity of the CPI to Exchange Rates: Distribution Margins, Imported Inputs, and Trade Exposure" Review of Economics and Statistics, May 2010, Vol. 92, No. 2: 392-407.

[44] Goldberg, Linda S. and Tille, Cédric, 2008. "Vehicle currency use in international trade," Journal of International Economics, Elsevier, vol. 76(2), pages 177-192, December

[45] Goldberg, P. K., and M. Knetter (1997): Goods Prices and Exchange Rates: What Have We Learned?," Journal of Economic Literature, 35(3), $1243\{1272$.

[46] Goldberg, Pinelopi K. and Frank Verboven (2005). "Market Integration and Convergence to the Law of One Price: Evidence from the European Car Market," Journal of International Economics, pp. 49-73, January 2005

[47] Goldberg, Pinelopi K. and Frank Verboven (2001). "The Evolution of Price Dispersion in European Car Markets", Review of Economic Studies, Oct. 2001, pp. 811-48.

[48] Gopinath, Gita and Oleg Itskhoki (2010a). "In Search of Real Rigidities" . NBER Macroeconomics Annual, 2010, Volume 25.

[49] __ (2010b). "Frequency of Price Adjustment and Pass-through". Quarterly Journal of Economics, May 2010, Volume 125(2).

[50] Gopinath, Gita Oleg Itskhoki, and Roberto Rigobon (2010b) "Currency Choice and Exchange Rate Pass-through" American Economic Review, March 2010, Volume 100(1).

[51] Gopinath, Gita and Roberto Rigobon (2008). "Sticky Borders", Quarterly Journal of Economics, May 2008, Volume 123(2).

[52] Guerrieri, Luca, Gust, Christopher, and David Lopez-Salido (2010) "International Competition and Inflation: A New Keynesian Perspecitve" , American Economic Journal: Macroeconomics, vol. 2 (October 2010), pp. 247-280

[53] Gust, Christopher, Sylvain Leduc and Roger Vigfusson "Trade Integration, Competition, and the Decline in Exchange-Rate Pass-Through", Journal of Monetary Economics 57, April 2010, 309-324.

[54] Hellerstein, Rebecca, 2008. "Who bears the cost of a change in the exchange rate? Pass-through accounting for the case of beer," Journal of International Economics, Elsevier, vol. 76(1), pages 14-32, September. 
[55] Imbs, Jeans, Haroon Mumtaz, Morten Ravn and Hélène Rey. "PPP Strikes Back: Aggregation and the Real Exchange Rate", Quarterly Journal of Economics, February 2005 .

[56] International Monetary Fund, (2007), World Economic Outlook Spillovers and Cycles in the Global Economy (Washington, DC: IMF, 2007).

[57] International Monetary Fund (2008), World Economic Outlook, 2008. How has globalization affected inflation?, Chapter 3, 97-134.

[58] Kamin, Steven B., Trevor A. Reeve, and Nathan Sheets (2007). "U.S. External Adjustment: Is It Disorderly? Is It Unique? Will It Disrupt the Rest of the World?" International Finance Discussion Papers, Federal Reserve Board, 2007-892 (April 2007)

[59] Knetter, Michael (1989). "Price Discrimination by U.S. and German Exporters," Amer. Econ. Rev.,Mar. 1989, 79(1), pp. 198-210.

[60] __ (1993)."International Comparisons of Price-to-Market Behavior," Amer. Econ. Rev., June 1993, 83(3), pp. 473-86.

[61] Kim, Mina, Deokwoo Nam, Jian Wang, and Jason Wu."International Trade Price Stickiness and Exchange Rate Pass-through in Micro Data: A Case Study on US-China Trade" Mimeo Federal Reserve Bank of Dallas, 2011

[62] Kimball, Miles S. (1995), "The Quantitative Analytics of the Basic Neomonetarist Model," Journal of Money, Credit, and Banking 27 (November): 1241-1277.

[63] Marazzi,Mario and Nathan Sheets, 2007. "Declining exchange rate pass-through to U.S. import prices: The potential role of global factors," Journal of International Money and Finance, Elsevier, vol. 26(6), pages 924-947, October.

[64] Marazzi,Mario, Nathan Sheets, Robert J.Vigfusson, Jon Faust, Joseph E. Gagnon, Jaime R.Marquez, Robert F.Martin, Trevor Reeve, and John H. Rogers. 2005. "Exchange Rate Pass-Through to U.S. Import Prices: Some New Evidence." Board of Governors of the Federal Reserve System International Finance Discussion Papers, no. 833,April.

[65] McCarthy, Jonathan (1999) "Pass-Through of Exchange Rates and Import Prices to Domestic Inflation in Some Industrialised Economies, BIS Working Paper No. 79 November 1999

[66] Melitz, Marc J., and Gianmarco Ottaviano. (2008). "Market Size, Trade, and Productivity." Review of Economic Studies, 75 (1): 295-316.

[67] Nakamura, Emi and Jón Steinsson (2010) "Lost in Transit: Product Replacement Bias and Pricing to Market" Mimeo, Columbia University. 
[68] Nakamura, Emi and Dawit Zerom (2010) "Accounting for Incomplete PassThrough" Review of Economic Studies, 77(3), 1192-1230, July 2010.

[69] Neiman, Brent, 2010. "Stickiness, synchronization, and passthrough in intrafirm trade prices," Journal of Monetary Economics, Elsevier, vol. 57(3), pages 295-308, April

[70] Ottaviano, G. I. P., Tabuchi, T. and Thisse, J.-F. (2002), "Agglomeration and Trade Revisited", International Economic Review, 43, 409-436.

[71] Overholt, William. (2003) "Exposing the Myths," South China Morning Post, November 17, 2003.

[72] Penning, Steven (2011). "Reacting to the Wrong Exchange Rate" [correct cite needed!], Mimeo, New York University

[73] Rogoff, Kenneth, "Impact of Globalization on Monetary Policy," in Federal Reserve Bank of Kansas City, The New Economic Geography: Effects and Policy Implications (2007).

[74] RYNn, Jonathan M. "Why Manufacturing and the infrastructure are central to the economy: A global vision of peace, prosperity, democracy, and ecological sustainability" posted on www.economicreconstruction.com on 11/1/2005.

[75] Schotт, Peter K. (2004). "Across-product versus within-product specialization in international trade." The Quarterly Journal of Economics, 119 (2): 647-678.

[76] Taylor, J. B. (2000), "Low Inflation, Pass-Through and the Pricing Power of Firms", European Economic Review, 44, 1389 - 1408.

[77] Verboven, Frank (1996). "International Price Discrimination in the European Car Market," Rand J. Econ., Summer 1996, 27(7), pp. 240-68.

[78] Woo, Wing T (1984): "Exchange Rates and the Prices of Nonfood, Nonfuel Products". Brookings Papers on Economic Activity, No. 2, pp. 511-30.

[79] YANG, Jiawen (1997). "Exchange Rate Pass-Through in U.S. Manufacturing Industries," The Review of Economics and Statistics, Vol. 79, No. 1. pp. 95-104., February 1997. 


\section{EUR and Yuan vs USD \\ Cummulative Changes Since 1999}

0.4
0.3
0.2
0.1
0

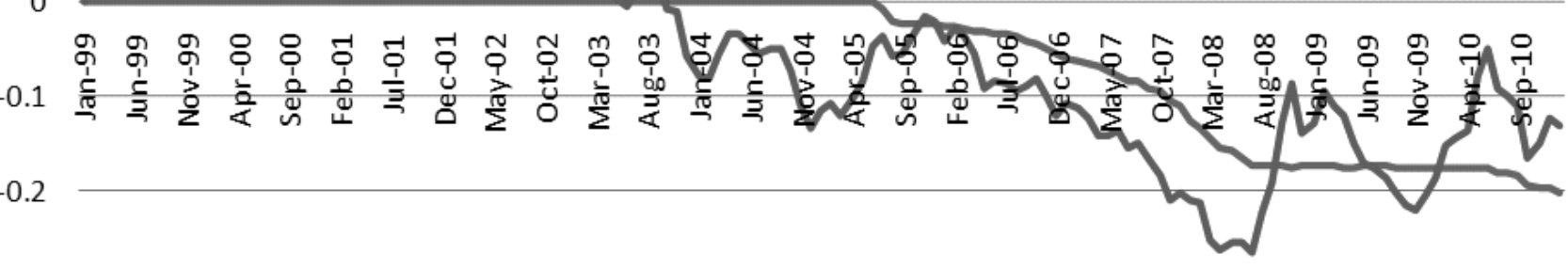

$-0.3$

$\longrightarrow$ USD/CNY USD/EUR

Figure 1

The Yuan and Chinese Import Prices

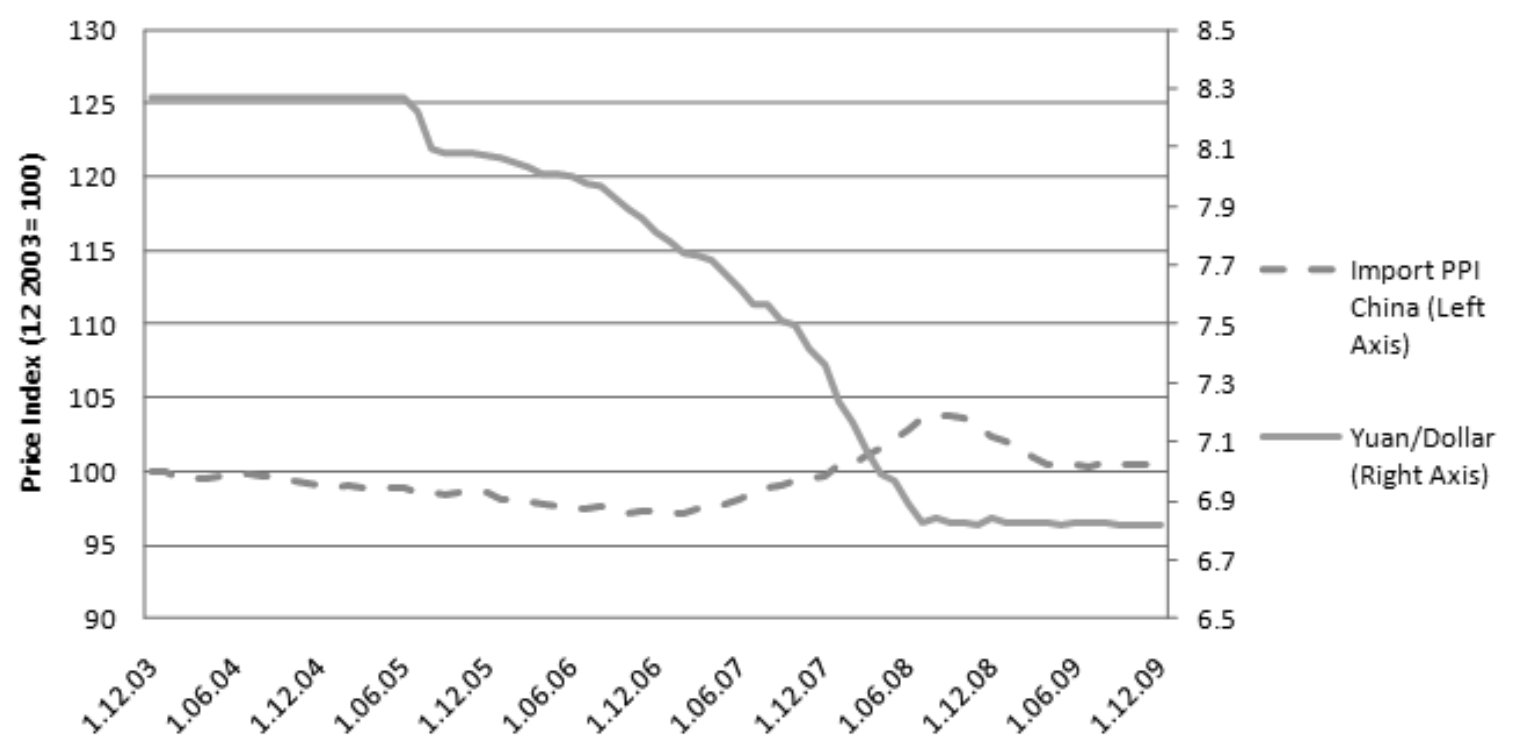

Figure 2 


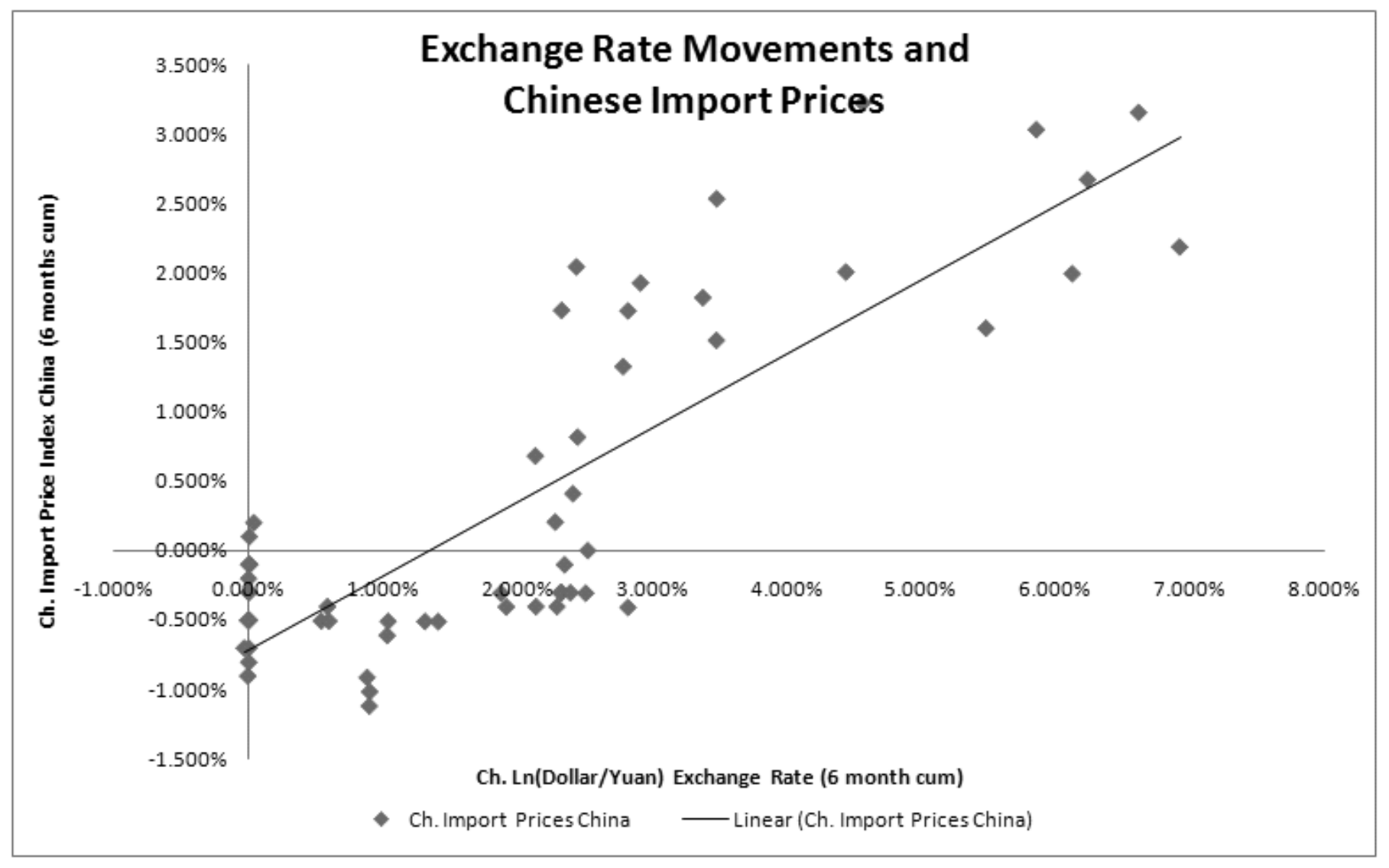

Figure 3

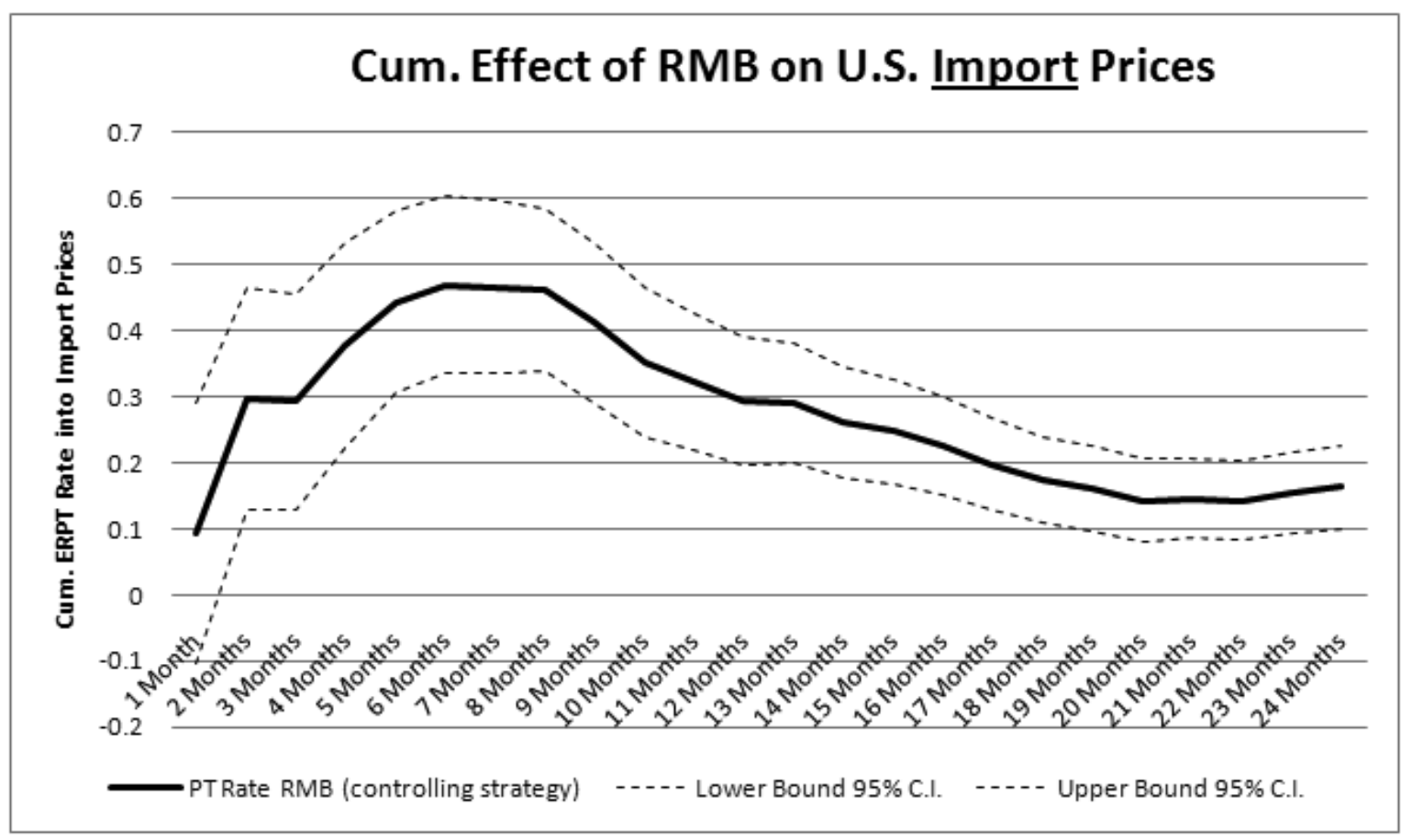

Figure 4 


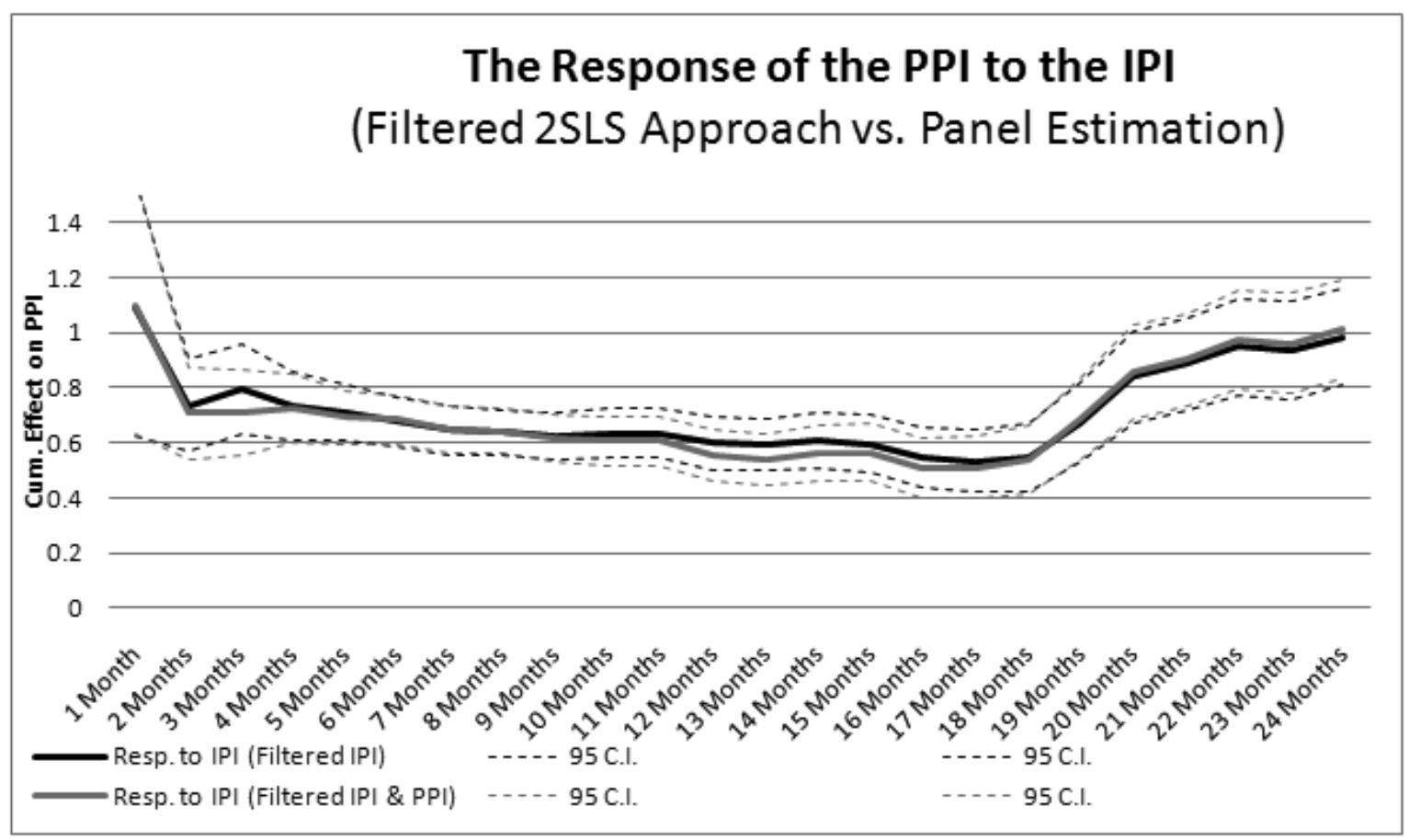

Figure 5

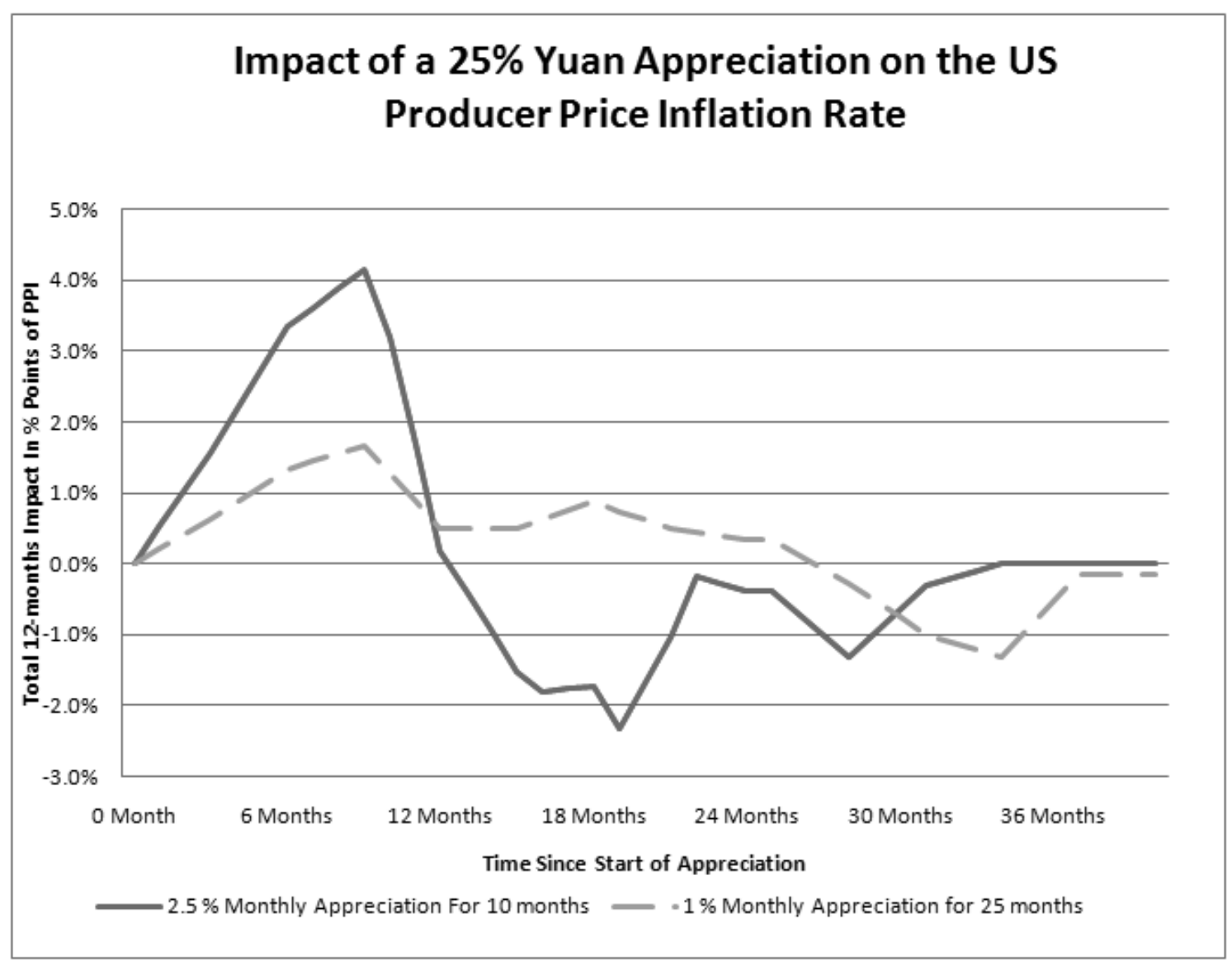

Figure 6 


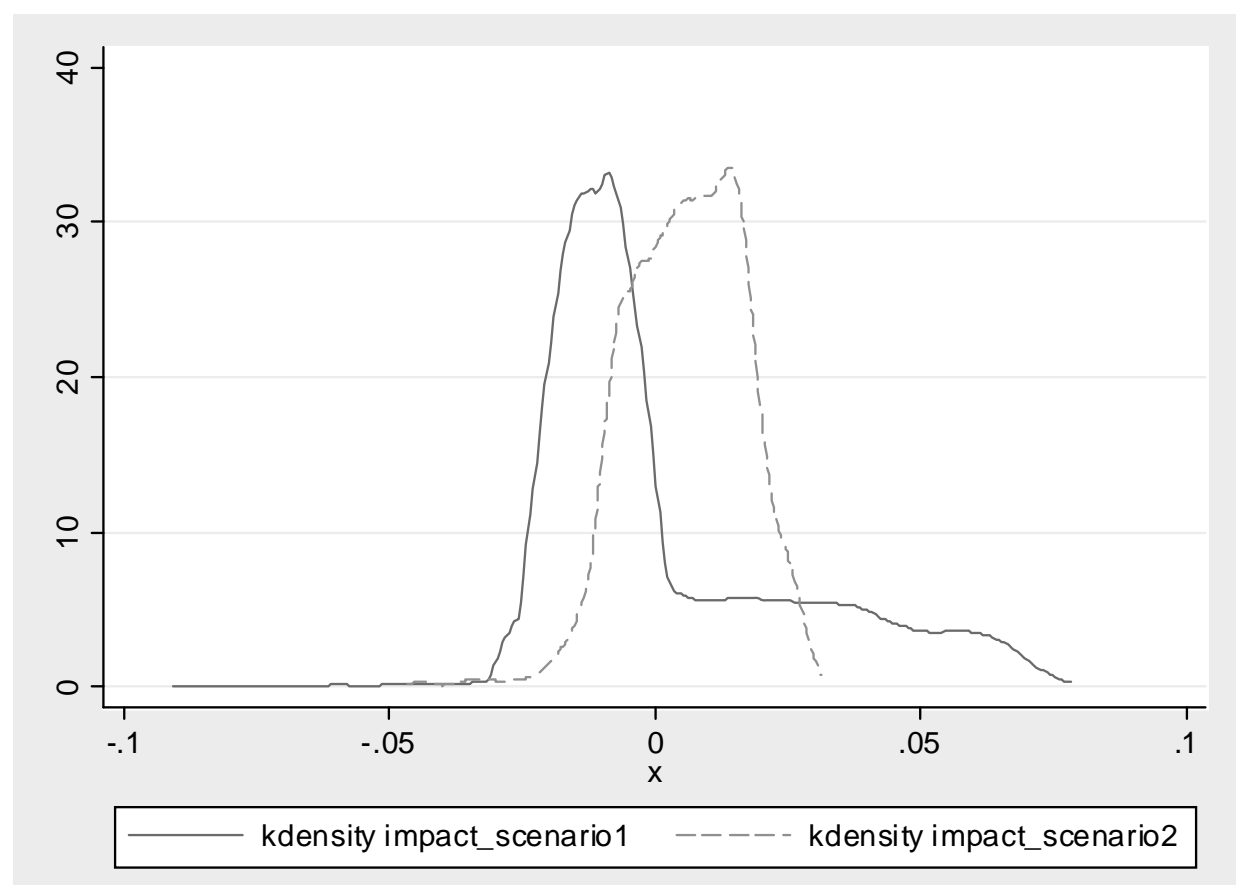

Figure 7

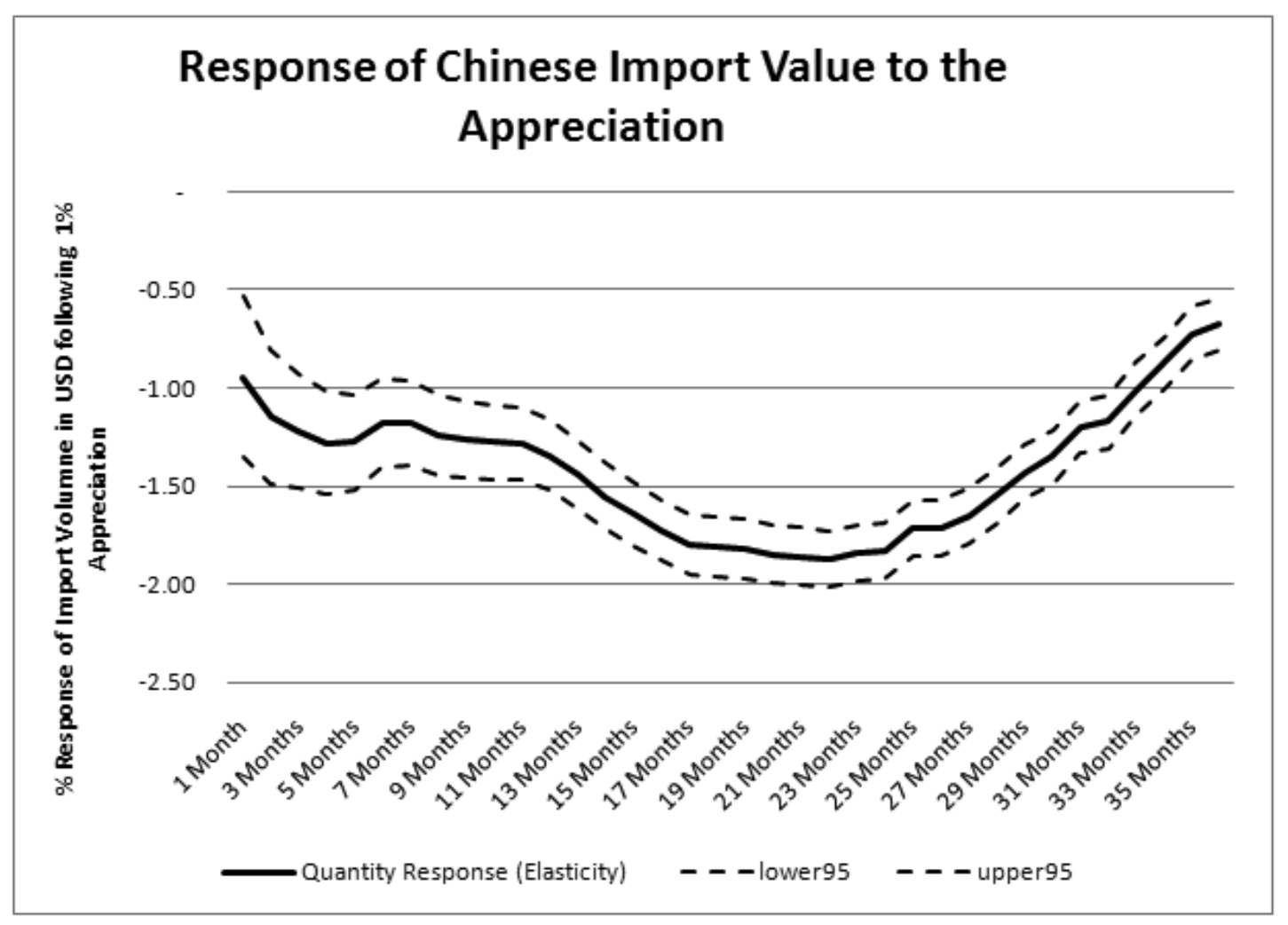

Figure 8 
Table 1 - Response of U.S. Import Prices to Yuan and Other Exchange Rate Movements (FE Panel Estimations)

\begin{tabular}{|c|c|c|c|c|c|c|c|c|}
\hline \multirow{4}{*}{$\begin{array}{r}\text { Sample: } \\
\text { Dependent Variable is }\end{array}$} & $(1)$ & $(2)$ & (3) & $(4)$ & $(5)$ & $(6)$ & \multirow{3}{*}{\multicolumn{2}{|c|}{$\begin{array}{c}(7) \quad(8) \\
\text { RMB PTon Filtered IPI } \\
\text { After June } 2005 \\
\text { (7)-(8): Cum Ch. In IPI } \\
\text { Filtered for Effect of (5)- } \\
\text { (6) }\end{array}$}} \\
\hline & \multicolumn{2}{|c|}{ (1)-(2): Simple PT Estimation } & \multicolumn{2}{|c|}{ (3)-(4): PT w. Controls } & \multicolumn{2}{|c|}{ (5)-(6): Effect of Controls } & & \\
\hline & \multicolumn{6}{|c|}{ (1)-(6): Cum. Ch. In U.S. Import Price Index at the NAICS $\overline{5-D i g i t ~ L e v e l ~}$} & & \\
\hline & 3 months & 6 months & 3 months & 6 months & 3 months & 6 months & 3 months & 6 months \\
\hline 3 Months Change USD/Yuan & $\begin{array}{c}0.5443 \\
{[0.0651]^{* *}}\end{array}$ & & $\begin{array}{c}0.2451 \\
{[0.0849]^{* *}}\end{array}$ & & & $\begin{array}{c}0.2921 \\
{[0.0833]^{* *}}\end{array}$ & & \\
\hline 6 Months Change USD/Yuan & & $\begin{array}{c}0.6393 \\
{[0.0505]^{* *}}\end{array}$ & & $\begin{array}{c}0.3061 \\
{[0.0713]^{* *}}\end{array}$ & & & & $\begin{array}{c}0.4691 \\
{[0.0686]^{* *}}\end{array}$ \\
\hline 3-Months Change USD/ROW Exrate & & & $\begin{array}{c}0.072 \\
{[0.0274]^{* *}}\end{array}$ & & $\begin{array}{c}0.1476 \\
{[0.0042]^{* *}}\end{array}$ & & & \\
\hline 6-Months Change USD/ROW Exrate & & & & $\begin{array}{c}0.0274 \\
{[0.0270]}\end{array}$ & & & $\begin{array}{c}0.2406 \\
{[0.0044]^{* *}}\end{array}$ & \\
\hline 3-Month Ch. Commodity Prices & & & $\begin{array}{c}0.047 \\
{[0.0064]^{* *}}\end{array}$ & & & $\begin{array}{c}0.0372 \\
{[0.0053]^{* *}}\end{array}$ & & \\
\hline 6-Month Ch. Commodity Prices & & & & $\begin{array}{c}0.0589 \\
{[0.0063]^{* *}}\end{array}$ & & & & $\begin{array}{c}0.0271 \\
{[0.0049]^{* *}}\end{array}$ \\
\hline 3-Months PPI Inflation China & $\begin{array}{c}0.0095 \\
{[0.0045]^{*}}\end{array}$ & & & & & & & \\
\hline 6-Months PPI Inflation China & & $\begin{array}{c}0.0273 \\
{[0.0059]^{* *}}\end{array}$ & & & & & & \\
\hline 3-Months PPI Inflation World & & & $\begin{array}{c}-0.0018 \\
{[0.0195]}\end{array}$ & & & $\begin{array}{c}-0.0119 \\
{[0.0192]}\end{array}$ & & \\
\hline 6-Months PPI Inflation World & & & & $\begin{array}{c}-0.0382 \\
{[0.0294]}\end{array}$ & & & & $\begin{array}{c}-0.1199 \\
{[0.0277]^{* *}}\end{array}$ \\
\hline Fixed Effects by Sector & $\mathrm{y}$ & $\mathrm{y}$ & $\mathrm{y}$ & $\mathrm{y}$ & $\mathrm{y}$ & $\mathrm{y}$ & $\mathrm{y}$ & $\mathrm{y}$ \\
\hline Seasonality Dummies & $\mathrm{n}$ & $\mathrm{n}$ & $\mathrm{y}$ & $\mathrm{y}$ & $\mathrm{y}$ & $\mathrm{y}$ & $\mathrm{y}$ & $\mathrm{y}$ \\
\hline Observations & 6708 & 6698 & 5877 & 5873 & 14117 & 5877 & 13736 & 5873 \\
\hline Number of Groups & 118 & 118 & 118 & 118 & 127 & 118 & 127 & 118 \\
\hline R-squared (Overall) & 0.01 & 0.03 & 0.05 & 0.08 & 0.09 & 0.03 & 0.19 & 0.04 \\
\hline
\end{tabular}




\begin{tabular}{|c|c|c|c|c|c|c|c|c|c|c|c|c|}
\hline & \multirow[t]{2}{*}{ (1) } & \multirow[t]{2}{*}{ (2) } & \multirow[t]{2}{*}{ (3) } & \multirow[t]{2}{*}{ (4) } & \multirow[t]{2}{*}{ (5) } & \multicolumn{2}{|c|}{ (6) } & \multirow[t]{2}{*}{ (7) } & \multirow[t]{2}{*}{ (8) } & \multirow[t]{2}{*}{ (9) } & \multicolumn{2}{|c|}{ (10) } \\
\hline & & & & & & (6-A) & (6-B) & & & & $(9-A)$ & $(9-B)$ \\
\hline Sample & $\begin{array}{l}\text { Baseline, } \\
\text { pre } 2005\end{array}$ & $\begin{array}{l}\text { Baseline, } \\
\text { post } 2005\end{array}$ & w. Controls & $\begin{array}{l}\text { w. Controls } \\
\text { post } 2005\end{array}$ & $\begin{array}{l}\text { Baseline IV, } \\
\text { post } 2005\end{array}$ & $\begin{array}{l}\text { Filtering PPI } \\
\text { pre } 2005\end{array}$ & $\begin{array}{c}\text { Filtered PPI } \\
\text { post } 2005\end{array}$ & $\begin{array}{l}\text { Baseline at } 6 \mathrm{~m} \\
\text { pre } 2005\end{array}$ & $\begin{array}{l}\text { Baseline at } 6 \mathrm{~m} \\
\text { post } 2005\end{array}$ & $\begin{array}{l}\text { Baseline IV, } \\
\text { post } 2005\end{array}$ & $\begin{array}{l}\text { Filtering PPI } \\
\text { pre } 2005\end{array}$ & $\begin{array}{r}\text { Filtered } \\
\text { post } 20\end{array}$ \\
\hline $\begin{array}{r}\text { Estimation Type: } \\
\text { Dependent Variable }\end{array}$ & FE Panel & FE Panel & $\begin{array}{l}\text { FE Panel } \\
\text { (1)-(5) \& (6A }\end{array}$ & $\begin{array}{l}\text { FE Panel } \\
\text { A): Cum Ch. PP }\end{array}$ & PI Panel IV & FE Panel & $\begin{array}{l}\text { Panel IV } \\
\text { Filtered PPI }\end{array}$ & FE Panel & FE Panel & $\begin{array}{l}\text { Panel IV } \\
\text { (8) \& (9A) Cur }\end{array}$ & $\begin{array}{c}\text { FE Panel } \\
\text { Im Ch. in PPI }\end{array}$ & $\begin{array}{r}\text { Panel } \\
\text { Filtered }\end{array}$ \\
\hline Horizon & 3 months & 3 months & 3 months & 3 months & 3 months & 3 months & 3 months & 6 months & 6 months & 6 months & 6 months & $6 \mathrm{mon}$ \\
\hline Cum. 3-M Change IPI & $\begin{array}{c}0.0954 \\
{[0.0192]^{* * *}}\end{array}$ & $\begin{array}{c}0.3493 \\
{[0.0051]^{* *}}\end{array}$ & $\begin{array}{c}0.132 \\
{[0.0219]^{* *}}\end{array}$ & $\begin{array}{c}0.3492 \\
{[0.0055]^{* *}}\end{array}$ & & & & & & & & \\
\hline $\begin{array}{l}\text { Cum. 3-M Change IPI, Filtered } \\
\text { (bold indicates 2SLS coefficient) }\end{array}$ & & & & & $\begin{array}{c}0.8002 \\
{[0.0833]^{* *}}\end{array}$ & & $\begin{array}{c}0.7115 \\
{[0.0796]^{* *}}\end{array}$ & & & & & \\
\hline 3-M Ch. USD/ROW Exrate & & & $\begin{array}{c}-0.0685 \\
{[0.0099] * *}\end{array}$ & $\begin{array}{c}-0.0899 \\
{[0.0085]^{* *}}\end{array}$ & & $\begin{array}{c}-0.0528 \\
{[0.0097] * *}\end{array}$ & & & & & & \\
\hline $\begin{array}{l}\text { 3-M PPI Inflation in all Trade } \\
\text { Partners (import weighted median) }\end{array}$ & & & $\begin{array}{c}0.0172 \\
{[0.0073]^{*}}\end{array}$ & $\begin{array}{c}-0.0168 \\
{[0.0061]^{* *}}\end{array}$ & $\begin{array}{c}-0.001 \\
{[0.0080]}\end{array}$ & & $\begin{array}{c}0.0024 \\
{[0.0076]}\end{array}$ & & & & & \\
\hline 3-M Ch. Commodity Prices (GSCl) & & & $\begin{array}{c}0.0021 \\
{[0.0023]}\end{array}$ & $\begin{array}{c}0.0252 \\
{[0.0017]^{* *}}\end{array}$ & $\begin{array}{c}0.0011 \\
{[0.0040]}\end{array}$ & & $\begin{array}{c}0.0108 \\
{[0.0038]^{* *}}\end{array}$ & & & & & \\
\hline Cum. 6-M Change IPI & & & & & & & & $\begin{array}{c}0.1372 \\
{[0.0229] * *}\end{array}$ & $\begin{array}{c}0.4412 \\
{[0.0053]^{* *}}\end{array}$ & & & \\
\hline $\begin{array}{l}\text { Cum. 6-M Change IPI, Filtered } \\
\text { (bold indicates 2SLS coefficient) }\end{array}$ & & & & & & & & & & $\begin{array}{c}0.6834 \\
{[0.0462] * *}\end{array}$ & & $\begin{array}{r}0.692 \\
{[0.0464}\end{array}$ \\
\hline 6-M Ch. USD/ROW Exrate & & & & & & & & $\begin{array}{l}-0.0271 \\
{[0.0113]^{*}}\end{array}$ & $\begin{array}{c}-0.1306 \\
{[0.0089]^{* *}}\end{array}$ & & $\begin{array}{c}0.0066 \\
{[0.0103]}\end{array}$ & \\
\hline $\begin{array}{l}\text { 6-M PPI Inflation in all Trade } \\
\text { Partners (import weighted median) }\end{array}$ & & & & & & & & $\begin{array}{c}0.0197 \\
{[0.0103]}\end{array}$ & $\begin{array}{c}-0.0316 \\
{[0.0100]^{* *}}\end{array}$ & $\begin{array}{c}0.0027 \\
{[0.0130]}\end{array}$ & & $\begin{array}{r}0.001 \\
{[0.013}\end{array}$ \\
\hline 6-M Ch. Commodity Prices (GSCI) & & & & & & & & $\begin{array}{c}0.003 \\
{[0.0025]}\end{array}$ & $\begin{array}{c}0.0281 \\
{[0.0018]^{* *}}\end{array}$ & $\begin{array}{c}0.0145 \\
{[0.0025]^{* *}}\end{array}$ & & $\begin{array}{r}0.013 \\
{[0.0025}\end{array}$ \\
\hline Jan-Dec Dummies & $\mathrm{n}$ & $\mathrm{y}$ & $\mathrm{y}$ & $\mathrm{y}$ & $\mathrm{y}$ & $\mathrm{y}$ & $\mathrm{y}$ & $\mathrm{y}$ & $\mathrm{y}$ & $\mathrm{y}$ & $\mathrm{y}$ & $\mathrm{y}$ \\
\hline Fixed Effects (by Sector) & $\mathrm{y}$ & $\mathrm{y}$ & $\mathrm{y}$ & $\mathrm{y}$ & $\mathrm{y}$ & $\mathrm{y}$ & $\mathrm{y}$ & $\mathrm{y}$ & $\mathrm{y}$ & $\mathrm{y}$ & $\mathrm{y}$ & $\mathrm{y}$ \\
\hline ormation On the First Stage of th & E 2SLS ES & Iations (In & Iment is Che & ge of $\operatorname{Ln}(U S$ & Yuan) at th & r $6 \mathrm{mhor}$ & and Instrui & ited Variable & Ch. In IPI I & ed for Effec & fROW EX & \\
\hline P-value Assoc. w. Anderson canon. cor. LR statis & & & & & $0.001<$ & & $0.001<$ & & & $0.001<$ & & 0.001 \\
\hline Max rej. Stock-Yogo Max IV Size Level & & & & & $10 \%$ & & $10 \%$ & & & $10 \%$ & & $10 \%$ \\
\hline Observations & 30729 & 25276 & 30729 & 20867 & 20867 & 30729 & 20867 & 29493 & 20854 & 20854 & 29493 & 2085 \\
\hline Number of Groups & 411 & 418 & 411 & 417 & 417 & 411 & 417 & 411 & 417 & 417 & 411 & 417 \\
\hline R-squared (OLS) & 0 & 0.16 & 0.01 & 0.19 & n/a & 0.01 & n/a & 0.01 & 0.29 & $\mathrm{n} / \mathrm{a}$ & 0.01 & $\mathrm{n} / \mathrm{a}$ \\
\hline
\end{tabular}


Table 3 - Robustness of Pass Through of Yuan and Other Exchange Rates into U.S. Import Prices (FE/AB Estimates)

\begin{tabular}{|c|c|c|c|c|c|c|c|}
\hline & \multirow{2}{*}{$\begin{array}{c}(1) \\
\text { not contr. for } \\
\text { PPI inflation abroad }\end{array}$} & \multirow{2}{*}{$\begin{array}{c}\text { (2) } \\
\text { only contr. For PPI } \\
\text { inflation in China }\end{array}$} & (3) & (4) & \multirow{2}{*}{$\begin{array}{c}\text { (5) } \\
\text { not contr. For } \\
\text { Commodities }\end{array}$} & \multirow{2}{*}{$\begin{array}{c}\text { (6) } \\
\text { AR Terms } \\
\text { (1 Year) }\end{array}$} & \multirow{2}{*}{$\begin{array}{c}\text { (7) } \\
\text { Atl. Matching } \\
\text { any NAICS } 6\end{array}$} \\
\hline & & & contro & ling for: & & & \\
\hline \multicolumn{8}{|c|}{ stimation - Dependent Variable is the 6-Months Change in the sectoral US PPI } \\
\hline 6-M Ch. US (Instrumented) & $\begin{array}{c}0.692063 \\
{[0.042384]^{* *}}\end{array}$ & $\begin{array}{c}0.703068 \\
{[0.045659]^{* *}}\end{array}$ & $\begin{array}{c}0.685688 \\
{[0.040981]^{* *}}\end{array}$ & $\begin{array}{c}0.771413 \\
{[0.048419] * *}\end{array}$ & $\begin{array}{c}0.847162 \\
{[0.030360]^{* *}}\end{array}$ & $\begin{array}{c}0.525245 \\
{[0.046996]^{* *}}\end{array}$ & $\begin{array}{c}0.66391 \\
{[0.048980]^{* *}}\end{array}$ \\
\hline $\begin{array}{l}\text { 6-M PPI Inflation in all Trade } \\
\text { Partners (import weighted median) }\end{array}$ & & $\begin{array}{c}0.004547 \\
{[0.002804]}\end{array}$ & & & & & \\
\hline 6-Months PPI Inflation China & & & $\begin{array}{c}0.00076 \\
{[0.012522]}\end{array}$ & $\begin{array}{c}0.014269 \\
{[0.012388]}\end{array}$ & $\begin{array}{c}0.048786 \\
{[0.009781]^{* *}}\end{array}$ & $\begin{array}{c}-0.015593 \\
{[0.012016]}\end{array}$ & $\begin{array}{c}0.007122 \\
{[0.014406]}\end{array}$ \\
\hline 6-M Ch. Capacity Utilization & & & $\begin{array}{c}-0.003681 \\
{[0.006081]}\end{array}$ & & & & \\
\hline 6-M. Ch. All Commodity Prices (GSCI) & $\begin{array}{c}0.013479 \\
{[0.001905]^{* *}}\end{array}$ & $\begin{array}{c}0.012696 \\
{[0.002104]^{* *}}\end{array}$ & $\begin{array}{c}0.014113 \\
{[0.002229]^{* *}}\end{array}$ & & & $\begin{array}{c}0.020353 \\
{[0.002164]^{* *}}\end{array}$ & $\begin{array}{c}0.014809 \\
{[0.003179] * *}\end{array}$ \\
\hline 6-M. Ch. Energy Commodity Prices (GSCI) & & & & $\begin{array}{c}0.005811 \\
{[0.002438]^{*}}\end{array}$ & & & \\
\hline 6-M. Ch. Metal Prices (GSCl) & & & & $\begin{array}{c}0.007692 \\
{[0.005920]}\end{array}$ & & & \\
\hline 6M Lag of IPI Price & & & & & & $\begin{array}{c}0.05861 \\
{[0.005536]^{* *}}\end{array}$ & \\
\hline 12M Lag of IPI Price & & & & & & $\begin{array}{c}-0.05272 \\
{[0.012375]^{* *}}\end{array}$ & \\
\hline \multicolumn{8}{|c|}{ Panel A: First Stage Estimation - Post 2005 Subsample - Dependent Variable is the 6-Months Change in the sectoral US Import PI } \\
\hline 6-M Ch. USD/Yuan & $\begin{array}{c}0.560428 \\
{[0.035789]^{* *}}\end{array}$ & $\begin{array}{c}0.527626 \\
{[0.036085]^{* *}}\end{array}$ & $\begin{array}{c}0.614712 \\
{[0.037057]^{* *}}\end{array}$ & $\begin{array}{c}0.613829 \\
{[0.043103]^{* *}}\end{array}$ & $\begin{array}{c}0.784188 \\
{[0.029276]^{* *}}\end{array}$ & $\begin{array}{c}0.363757 \\
{[0.034338]^{* *}}\end{array}$ & $\begin{array}{c}0.765356 \\
{[0.038123]^{* *}}\end{array}$ \\
\hline 6-M PPI Inflation in all Trade & & & -0.110165 & -0.069277 & -0.033503 & -0.080722 & -0.143549 \\
\hline Partner & & & {$[0.014471]^{* *}$} & {$[0.014837]^{* *}$} & {$[0.013288]^{*}$} & {$[0.013472]^{* *}$} & {$[0.015344]^{* *}$} \\
\hline 6-Months PPI Inflation China & & $\begin{array}{c}-0.023772 \\
{[0.003546]^{* *}}\end{array}$ & & & & & \\
\hline 6-M Ch. Capacity Utilization & & & $\begin{array}{c}0.082215 \\
{[0.008828]^{* *}}\end{array}$ & & & & \\
\hline 6-M. Ch. All Commodity Prices (GSCI) & $\begin{array}{c}0.023613 \\
{[0.002364]^{* *}}\end{array}$ & $\begin{array}{c}0.027106 \\
{[0.002419]^{* *}}\end{array}$ & $\begin{array}{c}0.017738 \\
{[0.002953]^{* *}}\end{array}$ & & & $\begin{array}{c}0.028414 \\
{[0.002441]^{* *}}\end{array}$ & $\begin{array}{c}0.048242 \\
{[0.002743]^{* *}}\end{array}$ \\
\hline 6-M. Ch. Energy Commodity Prices (GSCI) & & & & $\begin{array}{c}0.016906 \\
{[0.003058]^{* *}}\end{array}$ & & & \\
\hline 6-M. Ch. Metal Prices (GSCI) & & & & $\begin{array}{c}-0.019625 \\
{[0.007670]^{*}}\end{array}$ & & & \\
\hline 6M Lag of IPI Price & & & & & & $\begin{array}{l}0.12357 \\
{[0.006376] * *}\end{array}$ & \\
\hline 12M Lag of IPI Price & & & & & & $\begin{array}{c}-0.277732 \\
{[0.009970]^{* *}}\end{array}$ & \\
\hline \multicolumn{8}{|c|}{ Weak Indentification Tests } \\
\hline P-value Assoc. w. Anderson canon. cor. LR statistic & $0.001<$ & $0.001<$ & $0.001<$ & $0.001<$ & $0.001<$ & $0.001<$ & $0.001<$ \\
\hline Max rej. Stock-Yogo Max IV Size Level & $10 \%$ & $10 \%$ & $10 \%$ & $10 \%$ & $10 \%$ & $10 \%$ & $10 \%$ \\
\hline Observatio & 20854 & 20854 & 20854 & 20854 & 20854 & 20813 & 24129 \\
\hline Number of Groups & 417 & 41 & 41 & 417 & 417 & 417 & 477 \\
\hline R-squared (1st Stage) & 0.11 & 0.05 & 0.05 & 0.05 & 0.04 & 0.04 & 0.09 \\
\hline
\end{tabular}




\begin{tabular}{|c|c|c|c|c|c|c|c|c|c|c|}
\hline & (1) & (2) & (3) & (4) & (5) & (6) & (7) & (8) & (9) & (10) \\
\hline & Imports & re China & Labor & itensity & Deman & Elasticity & Input & itensity & Import Penetr & tion w/o China \\
\hline & Above Median & Below Median & Above Median & Below Median & Above Median & Below Median & none & at least some & Above Median & Below Median \\
\hline \multicolumn{11}{|c|}{ Panel A: ERPT into IPI - 3 Months Changes - Dep. Var is the 3-M Change in the US Import PPI } \\
\hline 3 M Change USD/Yuan & $\begin{array}{c}0.2843 \\
{[0.0461]^{* *}}\end{array}$ & $\begin{array}{c}0.2288 \\
{[0.1383]}\end{array}$ & $\begin{array}{c}0.3192 \\
{[0.0577]^{* *}}\end{array}$ & $\begin{array}{c}0.3829 \\
{[0.1217]^{* *}}\end{array}$ & $\begin{array}{c}0.2884 \\
{[0.1120]^{*}}\end{array}$ & $\begin{array}{c}0.284 \\
{[0.1014]^{* *}}\end{array}$ & $\begin{array}{c}0.2976 \\
{[0.0615]^{* *}}\end{array}$ & $\begin{array}{c}0.299 \\
{[0.1339]^{*}}\end{array}$ & $\begin{array}{c}0.3558 \\
{[0.0814]^{* *}}\end{array}$ & $\begin{array}{c}0.3443 \\
{[0.1303]^{* *}}\end{array}$ \\
\hline \multicolumn{11}{|c|}{ Panel B: ERPT into IPI - $\underline{6 \text { Months }}$ Changes - Dep. Var is the 6-M Change in the US Import PPI } \\
\hline 6 M Change USD/Yuan & $\begin{array}{c}0.437 \\
{[0.0386]^{* *}}\end{array}$ & $\begin{array}{c}0.3657 \\
{[0.1281]^{* *}}\end{array}$ & $\begin{array}{c}0.4871 \\
{[0.0478]^{* *}}\end{array}$ & $\begin{array}{c}0.5711 \\
{[0.1108]^{* *}}\end{array}$ & $\begin{array}{c}0.4169 \\
{[0.1026]^{* *}}\end{array}$ & $\begin{array}{c}0.4645 \\
{[0.0935]^{* *}}\end{array}$ & $\begin{array}{c}0.4715 \\
{[0.0481]^{* *}}\end{array}$ & $\begin{array}{c}0.4977 \\
{[0.1098]^{* *}}\end{array}$ & $\begin{array}{c}0.5057 \\
{[0.0732]^{* *}}\end{array}$ & $\begin{array}{c}0.5677 \\
{[0.1174]^{* *}}\end{array}$ \\
\hline \multicolumn{11}{|c|}{ Panel C: ERPT into PPI-3 Months Changes - Dep. Var is the 3-M Change in the US PPI } \\
\hline 3 M Change USD/Yuan & $\begin{array}{c}0.1475 \\
{[0.0206]^{* *}}\end{array}$ & $\begin{array}{c}0.6564 \\
{[0.0410]^{* *}}\end{array}$ & $\begin{array}{c}0.1456 \\
{[0.0204]^{* *}}\end{array}$ & $\begin{array}{c}0.4779 \\
{[0.0623]^{* *}}\end{array}$ & $\begin{array}{c}0.3664 \\
{[0.0521]^{* *}}\end{array}$ & $\begin{array}{c}0.1992 \\
{[0.0382]^{* *}}\end{array}$ & $\begin{array}{c}0.1623 \\
{[0.0221]^{* *}}\end{array}$ & $\begin{array}{c}0.3576 \\
{[0.0504]^{* *}}\end{array}$ & $\begin{array}{c}0.2469 \\
{[0.0433]^{* *}}\end{array}$ & $\begin{array}{c}0.3822 \\
{[0.0493]^{* *}}\end{array}$ \\
\hline \multicolumn{11}{|c|}{ Panel D: ERPT into PPI - 6 Months Changes - Dep. Var is the 6-M Change in the US PPI } \\
\hline 6 M Change USD/Yuan & $\begin{array}{c}0.2444 \\
{[0.0184]^{* *}}\end{array}$ & $\begin{array}{c}0.7223 \\
{[0.0336]^{* *}}\end{array}$ & $\begin{array}{c}0.2508 \\
{[0.0174]^{* *}}\end{array}$ & $\begin{array}{c}0.6264 \\
{[0.0593]^{* *}}\end{array}$ & $\begin{array}{c}0.5168 \\
{[0.0499]^{* *}}\end{array}$ & $\begin{array}{c}0.2813 \\
{[0.0356]^{* *}}\end{array}$ & $\begin{array}{c}0.27 \\
{[0.0195]^{* *}}\end{array}$ & $\begin{array}{c}0.4841 \\
{[0.0480]^{* *}}\end{array}$ & $\begin{array}{c}0.3752 \\
{[0.0421]^{* *}}\end{array}$ & $\begin{array}{c}0.5089 \\
{[0.0454]^{* *}}\end{array}$ \\
\hline \multicolumn{11}{|c|}{ Panel E: PT of IPI into PPI - IV Estimations - 3 Months Changes - Dep. Var is the 3-M Change in the US PPI } \\
\hline 3 M Change IPI & $\begin{array}{c}0.5585 \\
{[0.0894]^{* *}}\end{array}$ & $\begin{array}{c}0.924 \\
{[0.1487]^{* *}}\end{array}$ & $\begin{array}{c}0.4819 \\
{[0.0754]^{* *}}\end{array}$ & $\begin{array}{c}0.8507 \\
{[0.1224]^{* *}}\end{array}$ & $\begin{array}{c}0.945 \\
{[0.1514]^{* *}}\end{array}$ & $\begin{array}{c}0.5796 \\
{[0.1156]^{* *}}\end{array}$ & $\begin{array}{c}0.5699 \\
{[0.0906]^{* *}}\end{array}$ & $\begin{array}{c}0.8036 \\
{[0.1228]^{* *}}\end{array}$ & $\begin{array}{c}0.7192 \\
{[0.1304]^{* *}}\end{array}$ & $\begin{array}{c}0.7216 \\
{[0.1027]^{* *}}\end{array}$ \\
\hline \multicolumn{11}{|c|}{ Panel E: PT of IPI into PPI - IV Estimations - 6 Months Changes - Dep. Var is the 6-M Change in the US PPI } \\
\hline 6 M Change IPI & $\begin{array}{c}0.5844 \\
{[0.0482]^{* *}}\end{array}$ & $\begin{array}{c}0.8433 \\
{[0.0870]^{* *}}\end{array}$ & $\begin{array}{c}0.5324 \\
{[0.0397]^{* *}}\end{array}$ & $\begin{array}{c}0.7774 \\
{[0.0742]^{* *}}\end{array}$ & $\begin{array}{c}0.8976 \\
{[0.0863]^{* *}}\end{array}$ & $\begin{array}{c}0.5383 \\
{[0.0661]^{* *}}\end{array}$ & $\begin{array}{c}0.6008 \\
{[0.0486]^{* *}}\end{array}$ & $\begin{array}{c}0.739 \\
{[0.0728]^{* *}}\end{array}$ & $\begin{array}{c}0.7208 \\
{[0.0755]^{* *}}\end{array}$ & $\begin{array}{c}0.6588 \\
{[0.0597] * *}\end{array}$ \\
\hline \multicolumn{11}{|c|}{ Model Information: } \\
\hline Fixed Effects & $\mathrm{y}$ & $\mathrm{y}$ & $\mathrm{y}$ & $\mathrm{y}$ & $\mathrm{y}$ & $\mathrm{y}$ & $\mathrm{y}$ & $\mathrm{y}$ & $\mathrm{y}$ & $\mathrm{y}$ \\
\hline Filtering for ROW Exrate (3M or $6 \mathrm{M}$ ) & $\mathrm{y}$ & $\mathrm{y}$ & $\mathrm{y}$ & $\mathrm{y}$ & $\mathrm{y}$ & $\mathrm{y}$ & $\mathrm{y}$ & $\mathrm{y}$ & $\mathrm{y}$ & $\mathrm{y}$ \\
\hline Commodity Prices (3M or $6 \mathrm{M}$ ) & $\mathrm{y}$ & $\mathrm{y}$ & $\mathrm{y}$ & $\mathrm{y}$ & $\mathrm{y}$ & $\mathrm{y}$ & $\mathrm{y}$ & $\mathrm{y}$ & $\mathrm{y}$ & $\mathrm{y}$ \\
\hline Global Inflation (3M or 6M) & $\mathrm{y}$ & $\mathrm{y}$ & $\mathrm{y}$ & $\mathrm{y}$ & $\mathrm{y}$ & $\mathrm{y}$ & $\mathrm{y}$ & $\mathrm{y}$ & $\mathrm{y}$ & $\mathrm{y}$ \\
\hline \multicolumn{11}{|c|}{ Sample Information (Panel A) } \\
\hline No. Observations & 9045 & 8671 & 7310 & 8638 & 8271 & 8340 & 6383 & 12187 & 9662 & 6286 \\
\hline No. Groups & 54 & 54 & 42 & 52 & 49 & 50 & 39 & 75 & 57 & 37 \\
\hline
\end{tabular}




\section{Swiss National Bank Working Papers published since 2004:}

2004-1 Samuel Reynard: Financial Market Participation and the Apparent Instability of Money Demand

2004-2 Urs W. Birchler and Diana Hancock: What Does the Yield on Subordinated Bank Debt Measure?

2005-1 Hasan Bakhshi, Hashmat Khan and Barbara Rudolf: The Phillips curve under state-dependent pricing

2005-2 Andreas M. Fischer: On the Inadequacy of Newswire Reports for Empirical Research on Foreign Exchange Interventions

2006-1 Andreas M. Fischer: Measuring Income Elasticity for Swiss Money Demand: What do the Cantons say about Financial Innovation?

2006-2 Charlotte Christiansen and Angelo Ranaldo: Realized Bond-Stock Correlation: Macroeconomic Announcement Effects

2006-3 Martin Brown and Christian Zehnder: Credit Reporting, Relationship Banking, and Loan Repayment

2006-4 Hansjörg Lehmann and Michael Manz: The Exposure of Swiss Banks to Macroeconomic Shocks - an Empirical Investigation

2006-5 Katrin Assenmacher-Wesche and Stefan Gerlach: Money Growth, Output Gaps and Inflation at Low and High Frequency: Spectral Estimates for Switzerland

2006-6 Marlene Amstad and Andreas M. Fischer: Time-Varying Pass-Through from Import Prices to Consumer Prices: Evidence from an Event Study with Real-Time Data

2006-7 Samuel Reynard: Money and the Great Disinflation

2006-8 Urs W. Birchler and Matteo Facchinetti: Can bank supervisors rely on market data? A critical assessment from a Swiss perspective

2006-9 Petra Gerlach-Kristen: A Two-Pillar Phillips Curve for Switzerland

2006-10 Kevin J. Fox and Mathias Zurlinden: On Understanding Sources of Growth and Output Gaps for Switzerland

2006-11 Angelo Ranaldo: Intraday Market Dynamics Around Public Information Arrivals

2007-1 Andreas M. Fischer, Gulzina Isakova and Ulan Termechikov: Do FX traders in Bishkek have similar perceptions to their London colleagues? Survey evidence of market practitioners' views 
2007-2 Ibrahim Chowdhury and Andreas Schabert: Federal Reserve Policy viewed through a Money Supply Lens

2007-3 Angelo Ranaldo: Segmentation and Time-of-Day Patterns in Foreign Exchange Markets

2007-4 Jürg M. Blum: Why ‘Basel II' May Need a Leverage Ratio Restriction

2007-5 Samuel Reynard: Maintaining Low Inflation: Money, Interest Rates, and Policy Stance

2007-6 Rina Rosenblatt-Wisch: Loss Aversion in Aggregate Macroeconomic Time Series

2007-7 Martin Brown, Maria Rueda Maurer, Tamara Pak and Nurlanbek Tynaev: Banking Sector Reform and Interest Rates in Transition Economies: Bank-Level Evidence from Kyrgyzstan

2007-8 Hans-Jürg Büttler: An Orthogonal Polynomial Approach to Estimate the Term Structure of Interest Rates

2007-9 Raphael Auer: The Colonial Origins Of Comparative Development: Comment. A Solution to the Settler Mortality Debate

2007-10 Franziska Bignasca and Enzo Rossi: Applying the Hirose-Kamada filter to Swiss data: Output gap and exchange rate pass-through estimates

2007-11 Angelo Ranaldo and Enzo Rossi: The reaction of asset markets to Swiss National Bank communication

2007-12 Lukas Burkhard and Andreas M. Fischer: Communicating Policy Options at the Zero Bound

2007-13 Katrin Assenmacher-Wesche, Stefan Gerlach, and Toshitaka Sekine: Monetary Factors and Inflation in Japan

2007-14 Jean-Marc Natal and Nicolas Stoffels: Globalization, markups and the natural rate of interest

2007-15 Martin Brown, Tullio Jappelli and Marco Pagano: Information Sharing and Credit: Firm-Level Evidence from Transition Countries

2007-16 Andreas M. Fischer, Matthias Lutz and Manuel Wälti: Who Prices Locally? Survey Evidence of Swiss Exporters

2007-17 Angelo Ranaldo and Paul Söderlind: Safe Haven Currencies 
2008-1 Martin Brown and Christian Zehnder: The Emergence of Information Sharing in Credit Markets

2008-2 Yvan Lengwiler and Carlos Lenz: Intelligible Factors for the Yield Curve

2008-3 Katrin Assenmacher-Wesche and M. Hashem Pesaran: Forecasting the Swiss Economy Using VECX* Models: An Exercise in Forecast Combination Across Models and Observation Windows

2008-4 Maria Clara Rueda Maurer: Foreign bank entry, institutional development and credit access: firm-level evidence from 22 transition countries

2008-5 Marlene Amstad and Andreas M. Fischer: Are Weekly Inflation Forecasts Informative?

2008-6 Raphael Auer and Thomas Chaney: Cost Pass Through in a Competitive Model of Pricing-to-Market

2008-7 Martin Brown, Armin Falk and Ernst Fehr: Competition and Relational Contracts: The Role of Unemployment as a Disciplinary Device

2008-8 Raphael Auer: The Colonial and Geographic Origins of Comparative Development

2008-9 Andreas M. Fischer and Angelo Ranaldo: Does FOMC News Increase Global FX Trading?

2008-10 Charlotte Christiansen and Angelo Ranaldo: Extreme Coexceedances in New EU Member States' Stock Markets

2008-11 Barbara Rudolf and Mathias Zurlinden: Measuring capital stocks and capital services in Switzerland

2008-12 Philip Sauré: How to Use Industrial Policy to Sustain Trade Agreements

2008-13 Thomas Bolli and Mathias Zurlinden: Measuring growth of labour quality and the quality-adjusted unemployment rate in Switzerland

2008-14 Samuel Reynard: What Drives the Swiss Franc?

2008-15 Daniel Kaufmann: Price-Setting Behaviour in Switzerland - Evidence from CPI Micro Data

2008-16 Katrin Assenmacher-Wesche and Stefan Gerlach: Financial Structure and the Impact of Monetary Policy on Asset Prices

2008-17 Ernst Fehr, Martin Brown and Christian Zehnder: On Reputation: A Microfoundation of Contract Enforcement and Price Rigidity 
2008-18 Raphael Auer and Andreas M. Fischer: The Effect of Low-Wage Import Competition on U.S. Inflationary Pressure

2008-19 Christian Beer, Steven 0ngena and Marcel Peter: Borrowing in Foreign Currency: Austrian Households as Carry Traders

2009-1 Thomas Bolli and Mathias Zurlinden: Measurement of labor quality growth caused by unobservable characteristics

2009-2 Martin Brown, Steven Ongena and Pinar Yeșin: Foreign Currency Borrowing by Small Firms

2009-3 Matteo Bonato, Massimiliano Caporin and Angelo Ranaldo: Forecasting realized (co)variances with a block structure Wishart autoregressive model

2009-4 Paul Söderlind: Inflation Risk Premia and Survey Evidence on Macroeconomic Uncertainty

2009-5 Christian Hott: Explaining House Price Fluctuations

2009-6 Sarah M. Lein and Eva Köberl: Capacity Utilisation, Constraints and Price Adjustments under the Microscope

2009-7 Philipp Haene and Andy Sturm: Optimal Central Counterparty Risk Management

2009-8 Christian Hott: Banks and Real Estate Prices

2009-9 Terhi Jokipii and Alistair Milne: Bank Capital Buffer and Risk Adjustment Decisions

2009-10 Philip Sauré: Bounded Love of Variety and Patterns of Trade

2009-11 Nicole Allenspach: Banking and Transparency: Is More Information Always Better?

2009-12 Philip Sauré and Hosny Zoabi: Effects of Trade on Female Labor Force Participation

2009-13 Barbara Rudolf and Mathias Zurlinden: Productivity and economic growth in Switzerland 1991-2005

2009-14 Sébastien Kraenzlin and Martin Schlegel: Bidding Behavior in the SNB's Repo Auctions

2009-15 Martin Schlegel and Sébastien Kraenzlin: Demand for Reserves and the Central Bank's Management of Interest Rates

2009-16 Carlos Lenz and Marcel Savioz: Monetary determinants of the Swiss franc 
2010-1 Charlotte Christiansen, Angelo Ranaldo and Paul Söderlind: The Time-Varying Systematic Risk of Carry Trade Strategies

2010-2 Daniel Kaufmann: The Timing of Price Changes and the Role of Heterogeneity

2010-3 Loriano Mancini, Angelo Ranaldo and Jan Wrampelmeyer: Liquidity in the Foreign Exchange Market: Measurement, Commonality, and Risk Premiums

2010-4 Samuel Reynard and Andreas Schabert: Modeling Monetary Policy

2010-5 Pierre Monnin and Terhi Jokipii: The Impact of Banking Sector Stability on the Real Economy

2010-6 Sébastien Kraenzlin and Thomas Nellen: Daytime is money

2010-7 Philip Sauré: Overreporting Oil Reserves

2010-8 Elizabeth Steiner: Estimating a stock-flow model for the Swiss housing market

2010-9 Martin Brown, Steven Ongena, Alexander Popov, and Pinar Yeșin: Who Needs Credit and Who Gets Credit in Eastern Europe?

2010-10 Jean-Pierre Danthine and André Kurmann: The Business Cycle Implications of Reciprocity in Labor Relations

2010-11 Thomas Nitschka: Momentum in stock market returns: Implications for risk premia on foreign currencies

2010-12 Petra Gerlach-Kristen and Barbara Rudolf: Macroeconomic and interest rate volatility under alternative monetary operating procedures

2010-13 Raphael Auer: Consumer Heterogeneity and the Impact of Trade Liberalization: How Representative is the Representative Agent Framework?

2010-14 Tommaso Mancini Griffoli and Angelo Ranaldo: Limits to arbitrage during the crisis: funding liquidity constraints and covered interest parity

2010-15 Jean-Marc Natal: Monetary Policy Response to Oil Price Shocks

2010-16 Kathrin Degen and Andreas M. Fischer: Immigration and Swiss House Prices

2010-17 Andreas M. Fischer: Immigration and large banknotes

2010-18 Raphael Auer: Are Imports from Rich Nations Deskilling Emerging Economies? Human Capital and the Dynamic Effects of Trade 
2010-19 Jean-Pierre Danthine and John B. Donaldson: Executive Compensation: A General Equilibrium Perspective

2011-1 Thorsten Beck and Martin Brown: Which Households Use Banks? Evidence from the Transition Economies

2011-2 Martin Brown, Karolin Kirschenmann and Steven Ongena: Foreign Currency Loans Demand or Supply Driven?

2011-3 Victoria Galsband and Thomas Nitschka: Foreign currency returns and systematic risks

2011-4 Francis Breedon and Angelo Ranaldo: Intraday patterns in FX returns and order flow

2011-5 Basil Guggenheim, Sébastien Kraenzlin and Silvio Schumacher: Exploring an uncharted market: Evidence on the unsecured Swiss franc money market

2011-6 Pamela Hall: Is there any evidence of a Greenspan put?

2011-7 Daniel Kaufmann and Sarah Lein: Sectoral Inflation Dynamics, Idiosyncratic Shocks and Monetary Policy

2011-8 Iva Cecchin: Mortgage Rate Pass-Through in Switzerland

2011-9 Raphael A. Auer, Kathrin Degen and Andreas M. Fischer: Low-Wage Import Competition, Inflationary Pressure, and Industry Dynamics in Europe

2011-10 Raphael A. Auer and Philip Sauré: Spatial Competition in Quality, Demand-Induced Innovation, and Schumpeterian Growth

2011-11 Massimiliano Caporin, Angelo Ranaldo and Paolo Santucci de Magistris: On the Predictability of Stock Prices: a Case for High and Low Prices

2011-12 Jürg Mägerle and Thomas Nellen: Interoperability between central counterparties

2011-13 Sylvia Kaufmann: K-state switching models with endogenous transition distributions

2011-14 Sébastien Kraenzlin and Benedikt von Scarpatetti: Bargaining Power in the Repo Market

2012-01 Raphael A. Auer: Exchange Rate Pass-Through, Domestic Competition, and Inflation: Evidence from the 2005/08 Revaluation of the Renminbi 
Swiss National Bank Working Papers are also available at www.snb.ch, section Publications/Research Subscriptions or individual issues can be ordered at Swiss National Bank, Fraumünsterstrasse 8, CH-8022 Zurich, fax+41 4463181 14, E-mail library@snb.ch 